\title{
High-Level IGF1R Expression is Required for Leukemia-Initiating Cell Activity in T-ALL and is Supported by Notch Signaling
}

\section{Citation}

Medyouf, Hind, Samuel Gusscott, Hongfang Wang, Jen-Chieh Tseng, Carol Wai, Oksana Nemirovsky, Andreas Trumpp, et al. 2011. High-level IGF1R expression is required for leukemiainitiating cell activity in T-ALL and is supported by Notch signaling. Journal of Experimental Medicine 208(9): 1809-1822.

\section{Published Version}

doi:10.1084/jem.20110121

\section{Permanent link}

http://nrs.harvard.edu/urn-3:HUL.InstRepos:8615964

\section{Terms of Use}

This article was downloaded from Harvard University's DASH repository, and is made available under the terms and conditions applicable to Other Posted Material, as set forth at http:// nrs.harvard.edu/urn-3:HUL.InstRepos:dash.current.terms-of-use\#LAA

\section{Share Your Story}

The Harvard community has made this article openly available.

Please share how this access benefits you. Submit a story.

Accessibility 


\title{
High-level IGF1R expression is required for leukemia-initiating cell activity in T-ALL and is supported by Notch signaling
}

\author{
Hind Medyouf, ${ }^{1}$ Samuel Gusscott, ${ }^{1}$ Hongfang Wang, ${ }^{2}$ Jen-Chieh Tseng, ${ }^{3}$ \\ Carol Wai, ${ }^{1}$ Oksana Nemirovsky, ${ }^{1}$ Andreas Trumpp, ${ }^{4}$ Francoise Pflumio, ${ }^{5}$ \\ Joan Carboni, ${ }^{6}$ Marco Gottardis, ${ }^{6}$ Michael Pollak, ${ }^{7}$ Andrew L. Kung, ${ }^{3,8}$ \\ Jon C. Aster, ${ }^{2}$ Martin Holzenberger, ${ }^{9}$ and Andrew P. Weng ${ }^{1}$
'Terry Fox Laboratory/Department of Pathology, BC Cancer Agency, Vancouver, BC, V52 1L3 Canada
2Department of Pathology, Brigham \& Women's Hospital/Harvard Medical School, Boston, MA 02115 ${ }^{3}$ Lurie Family Imaging Center, Dana-Farber Cancer Institute, Boston, MA 02115
${ }^{4}$ Heidelberg Institute for Stem Cell Technology and Experimental Medicine (HI-STEM), and Division of Stem Cells and Cancer, German Cancer Research Center (DKFZ), D-69120 Heidelberg, Germany
${ }_{5}^{5}$ LSHL/IRCM, Institut National de la Santé et de la Recherche Médicale U967, Université Paris 7, CEA, 92265 Fontenay-aux- Roses, France
${ }^{6}$ Oncology Drug Discovery, Bristol-Myers Squibb Company, Princeton, NJ 08543
${ }^{7}$ Department of Oncology, McGill University, Montreal, Quebec, H3T 1E2 Canada
${ }^{9}$ Centre de Recherche Institut National de la Santé et de la Recherche Médicale Saint-Antoine, Université Pierre-et-Marie-
Curie, 75571 Paris, France \\ ¿Department of Pediatric Oncology, Dana-Farber Cancer Institute and Children's Hospital/Harvard Medical School, Boston, MA 02115
}

T cell acute lymphoblastic leukemia (T-ALL) is an aggressive cancer of immature T cells that often shows aberrant activation of Notch 1 and PI3K-Akt pathways. Although mutations that activate Pl3K-Akt signaling have previously been identified, the relative contribution of growth factor-dependent activation is unclear. We show here that pharmacologic inhibition or genetic deletion of insulin-like growth factor 1 receptor (IGF1R) blocks the growth and viability of T-ALL cells, whereas moderate diminution of IGF1R signaling compromises leukemia-initiating cell (LIC) activity as defined by transplantability in syngeneic/ congenic secondary recipients. Furthermore, IGF1R is a Notch1 target, and Notch1 signaling is required to maintain IGF1R expression at high levels in T-ALL cells. These findings suggest effects of Notch on LIC activity may be mediated in part by enhancing the responsiveness of T-ALL cells to ambient growth factors, and provide strong rationale for use of IGF1R inhibitors to improve initial response to therapy and to achieve long-term cure of patients with T-ALL.

\author{
CORRESPONDENCE \\ Andrew P. Weng: \\ aweng@bccrc.ca \\ OR \\ Hind Medyouf: \\ h.medyouf@dkfz-heidelberg.de \\ Abbreviations used: 4-OHT, \\ 4-hydroxytamoxifen; ChIP, \\ chromatin immunoprecipita- \\ tion; LIC, leukemia-initiating \\ cell; NOD, nonobese diabetic; \\ qPCR, quantitative PCR; \\ T-ALL, T cell acute lympho- \\ blastic leukemia.
}

T cell acute lymphoblastic leukemia (T-ALL) is an aggressive cancer of immature $\mathrm{T}$ cell progenitors that often shows aberrant activation of NOTCH1 and PI3K-Akt pathways. Activating mutations of Notch1 occur in $>50 \%$ of cases of T-ALL (Weng et al., 2004), whereas mutations in related Notch pathway elements such as Sel10/Fbw7 occur in $8-16 \%$ of cases (O'Neil et al., 2007; Thompson et al., 2007). PI3K-Akt pathway activation occurs in $>85 \%$ of cases (Silva et al., 2008) via diverse mechanisms,

H. Medyouf's present address is Heidelberg Institute for Stem Cell Technology and Experimental Medicine (HI-STEM), and Division of Stem Cells and Cancer, German Cancer Research Center (DKFZ), D-69120 Heidelberg, Germany including mutation or inactivation of PTEN (Kawamura et al., 1999; Perentesis et al., 2004; Maser et al., 2007; Palomero et al., 2007; Silva et al., 2008; Gutierrez et al., 2009) and mutation of PIK3 and Akt (Kawamura et al., 1999; Gutierrez et al., 2009). Activation of PI3K-Akt has been shown to collaborate with Notch in leukemogenesis (Medyouf et al., 2010), enhance growth of established leukemias (Chiarini et al., 2009; Cullion et al., 2009; Levy et al., 2009; Sanda et al., 2010), and in some contexts to

\footnotetext{
- 2011 Medyouf et al. This article is distributed under the terms of an Attribution-Noncommercial-Share Alike-No Mirror Sites license for the first Attribution-Noncommercial-Share Alike-No Mirror Sites license for the first
six months after the publication date (see http://www.rupress.org/terms). After six months it is available under a Creative Commons License (Attribution-Noncommercial-Share Alike 3.0 Unported license, as described at http://creativecommons.org/licenses/by-nc-sa/3.0/).
} 
relieve dependence on Notch signaling (Palomero et al., 2007). For cases that lack such mutations, however, the mechanisms that support activation of the pathway are unknown. More generally, it is also unknown to what extent growth factor-dependent stimulation of cognate receptor tyrosine kinases (RTKs) contributes to the net signaling output.

Although previous works have focused on the role of IL-7 signaling in T-ALL, including effects on downstream PI3K-Akt activation (Dibirdik et al., 1991; Barata et al., 2004a,b,c, 2005; González-Garcia et al., 2009; Shochat et al., 2011; Silva et al., 2011), we considered that insulin-like growth factor (IGF)-1 receptor (IGF1R) may also play an important role. IGFs and their receptors regulate normal cell growth and contribute to transformation and growth of malignant cells in many contexts (Pollak et al., 2004). IGF1 and IGF2 bind to IGF1R, a transmembrane receptor tyrosine kinase (RTK), thereby initiating a cascade of downstream phosphorylation events that bifurcates along both PI3K-Akt and Ras-Raf-MAPK pathways. PI3K-Akt activation leads to enhanced cellular metabolism and protein synthesis via mTOR and enhanced survival via $\mathrm{BAD} / \mathrm{Bcl} 2, \mathrm{p} 53, \mathrm{NF}-\mathrm{kB}$, and FOXOs, whereas Ras-Raf-MAPK activation generally results in increased cellular proliferation (Pollak et al., 2004; Greer and Brunet, 2005). Signaling through IGF1R has also been implicated in self-renewal of stem cells, both in embryonic (Bendall et al., 2007) and hematopoietic (Ivanova et al., 2002) contexts.

\section{RESULTS}

\section{IGF1R is broadly expressed in T-ALL}

To begin to address a potential role for IGF1R in T-ALL, we assessed IGF1R expression in mouse and human T-ALL cells. Analysis of IGF1R by Western blot and flow cytometry revealed IGF1R was expressed in all cases examined, albeit at varying levels (Fig. 1). For human cells, we examined both established cell lines and xenograft-expanded primary human samples (Weng et al., 2004; Weng et al., 2006; Medyouf et al., 2010). For mouse cells, we examined primary leukemias derived by retroviral transduction/transplantation of bone marrow with an activated form of NOTCH1 termed $\Delta \mathrm{E}$ (Pear et al., 1996). To confirm IGF1R-stimulated PI3KAkt in these contexts, we pulsed serum-starved leukemia cells with recombinant IGF-1 and measured phospho-Akt activation by flow cytometry. We observed that both human and mouse leukemia cells respond robustly to IGF-1 stimulation under these conditions (Fig. S1).

\section{Pharmacologic inhibition of IGF1R compromises T-ALL cell growth}

To assess the extent to which T-ALL cells are dependent on IGF1R signaling, we used pharmacologic IGF1R inhibitors. Most small molecule IGF1R inhibitors also affect insulin receptor caused by their close homology and at higher doses may be expected to cross react with more distantly related receptor tyrosine kinases. One such inhibitor, BMS-536924 (Wittman et al., 2005), substantially inhibited growth/proliferation of both mouse and human leukemia cells in vitro (Fig. 2 and Fig. S2). Primary leukemia cells were generally more sensitive to BMS-536924 with IC50 values in the 0.1$1.0 \mu \mathrm{M}$ range, whereas established cell lines required somewhat higher doses $(2-4 \mu \mathrm{M})$ to achieve similar effects. As expected, BMS-536924 completely suppressed Akt activation by both IGF-1 and insulin in human and mouse T-ALL cells (Fig. S1).

We next examined whether blocking antibodies against IGF1R, which might be expected to exhibit a higher degree of specificity than small molecule kinase inhibitors, would recapitulate effects seen with BMS-536924. The IGF1Rblocking antibody $\alpha$ IR 3 substantially inhibited proliferation in three of four primary human leukemias tested (Fig. 2 B, rightmost column). Notably, the one resistant case (K419) expressed lower levels of IGF1R compared with the others
A
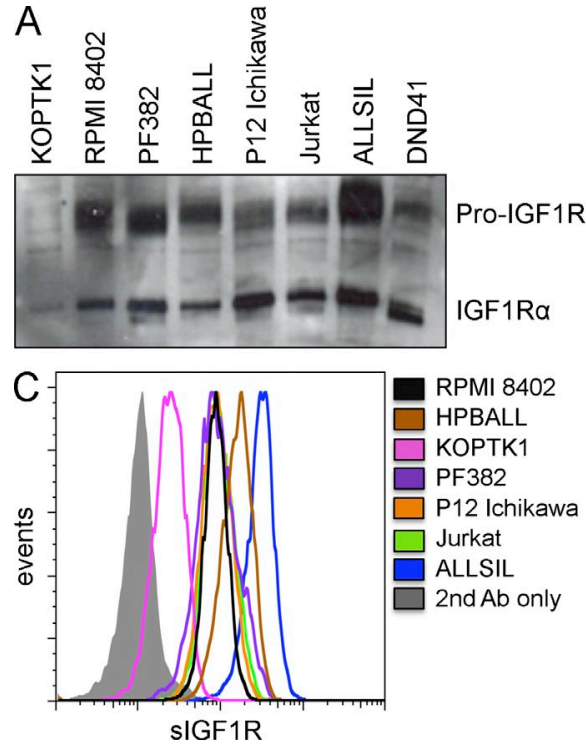
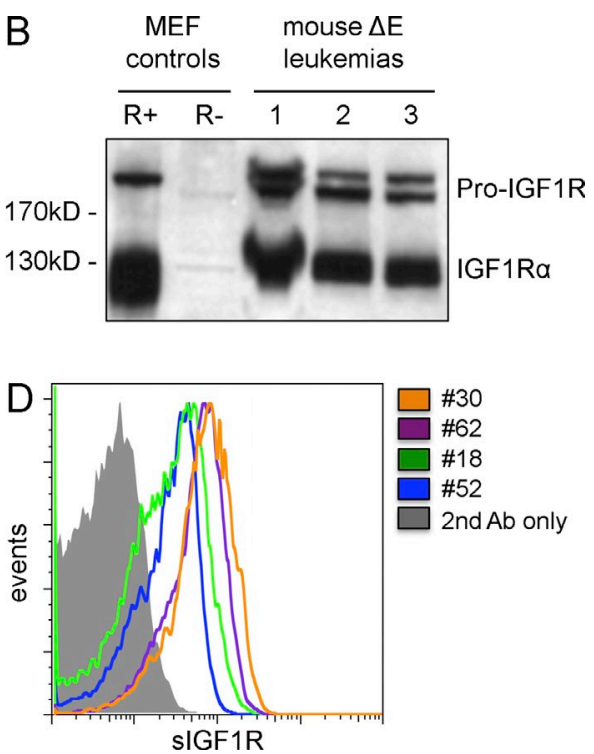

Figure 1. IGF1R is expressed broadly in human and mouse T-ALL. ( $A$ and $B$ ) Western blot and ( $C$ and D) flow cytometric analysis of total and surface IGF1R protein expression, respectively, from human cell lines ( $\mathrm{A}$ and $\mathrm{C}$ ), primary mouse leukemias (B) derived by retroviral transduction/transplantation of bone marrow with an activated form of Notch1 termed $\Delta \mathrm{E}$, and xenograft-expanded primary human samples (D). Western blot controls in (B) are mouse embryonic fibroblasts derived from IGF1Rnull mouse embryos $(\mathrm{R}-)$ and the same cells stably transfected with an IGF1R cDNA expression construct ( $R+$ ). At least 20,000 events were collected within each gate for all flow cytometry assays. Data depicted are representative of at least two independent experiments. 
(Fig. S3) and showed minimal response to IGF-1 stimulation (unpublished data), suggesting the effect of BMS-536924 on this particular tumor may be mediated by inhibition of insulin receptor. In contrast, case M69 is highly sensitive to $\alpha$ IR3, but largely resistant to BMS-536924, raising the possibility of either off-target antibody effects or inherent drug resistance. Notwithstanding these exceptions, the overall results support that pharmacologic inhibition of IGF1R signaling can significantly inhibit the growth of most T-ALL cells.

\section{Generation of T cell leukemias with reduced IGF1R signaling}

We next used a genetic approach to further explore the effects of reduced and/or complete loss of IGF1R on T-ALL cells. Specifically, we generated primary mouse T cell leukemias by transduction of bone marrow from conditional IGF1R mice with $\operatorname{Notch} 1(\Delta \mathrm{E})$ retrovirus, followed by transplantation into congenic WT recipients. The conditional allele used, IGF1R ${ }^{\text {neo }}$, carries loxP sites flanking the third exon, but also retains a loxP-flanked neo cassette within the second intron (Fig. 3 A). This neo cassette interferes with normal transcript splicing and results in reduced expression of full-length IGF1R protein in homozygous IGF1R neo/neo cells (Holzenberger et al., 2000). Despite the decreased level of IGF1R expression, we were able to generate primary IGF1R $^{\text {neo/neo }}$ leukemias with $\operatorname{Notch} 1(\Delta \mathrm{E})$ retrovirus, albeit with slightly increased latency as compared with WT background (median survival 64.5 vs. 51.5 d; Fig. 3 B). All other disease parameters (penetrance, immunophenotype, histology, disease distribution, and extent) were highly comparable to control
IGF1R $^{+/+} \Delta$ E leukemias (Fig. 3, C and D; and not depicted). Importantly, we confirmed that IGF1R ${ }^{\text {neo/neo }} \Delta \mathrm{E}$ leukemias expressed reduced levels of full-length IGF1R protein $(32 \pm$ $20 \%$ of levels observed in IGF1R ${ }^{+/+} \Delta \mathrm{E}$ leukemias, $n=7$; Fig. $3 \mathrm{E}$ and not depicted).

\section{Reduced IGF1R signaling compromises leukemia-initiating cell (LIC) activity}

To explore whether the increased latency observed for $\mathrm{IGF}_{\mathrm{R}}{ }^{\text {neo/neo }} \Delta \mathrm{E}$ leukemias might be caused by delayed transformation or a reduced net proliferative rate, we performed serial transplantation of IGF1R ${ }^{+/+}$and IGF1R ${ }^{\text {neo/neo }} \Delta \mathrm{E}$ leukemias into syngeneic/congenic recipients by tail vein injection. Unexpectedly, we observed that only a subset of IGF1R neo/neo primary leukemias was capable of transferring disease to secondary recipients. Among 11 independent primary leukemias assessed, 7 (64\%) were nontransplantable, $2(18 \%)$ were transplantable in a minority of recipients, and $2(18 \%)$ were fully transplantable, including one with prolonged latency (Fig. 4 A). In contrast, all IGF1R ${ }^{+/+}$primary leukemias were fully transplantable and exhibited short latencies. We also performed tertiary and quarternary transplants for a subset of cases. The IGF1R neo/neo leukemia with prolonged latency in secondary recipients (\#3115) failed to produce disease in tertiary recipients, whereas the other transplantable IGF1R neo/neo leukemia (\#3105) and all IGF1R ${ }^{+/+}$ leukemias produced short latency disease in all tertiary and quarternary recipients (Table S1). Notably, injection of $I_{G F 1 R}$ neo/neo leukemia cells directly into the femoral bone marrow space of recipient mice failed to produce leukemia, suggesting that their defect in transplantability is not caused by impaired homing to the bone marrow (Fig. 4 B). Thus, these results indicate that although moderate levels of IGF1R signaling are sufficient for expansion of bulk leukemia cells, higher levels are required to

Figure 2. Pharmacologic inhibition of IGF1R blocks growth of T-ALL cells. Flow cytometric analysis of cell proliferation by BrdU incorporation after treatment with a small molecule IGF1R inhibitor (BMS536924) versus DMSO vehicle (mock), or IGF1R blocking antibody ( $\alpha$ IR3), for 48-72 h in vitro. (A) Three representative independent primary mouse Notch $1(\Delta \mathrm{E})$ leukemias (\#324, \#327, \#329). (B) Four independent xenograft-expanded primary human T-ALL samples (D115, K419, K424, and M69). (C) Two human T-ALL cell lines (ALLSIL and HPBALL). Error bars indicate standard deviation for assays performed in triplicate. Data depicted are representative of at least three independent experiments. 
A
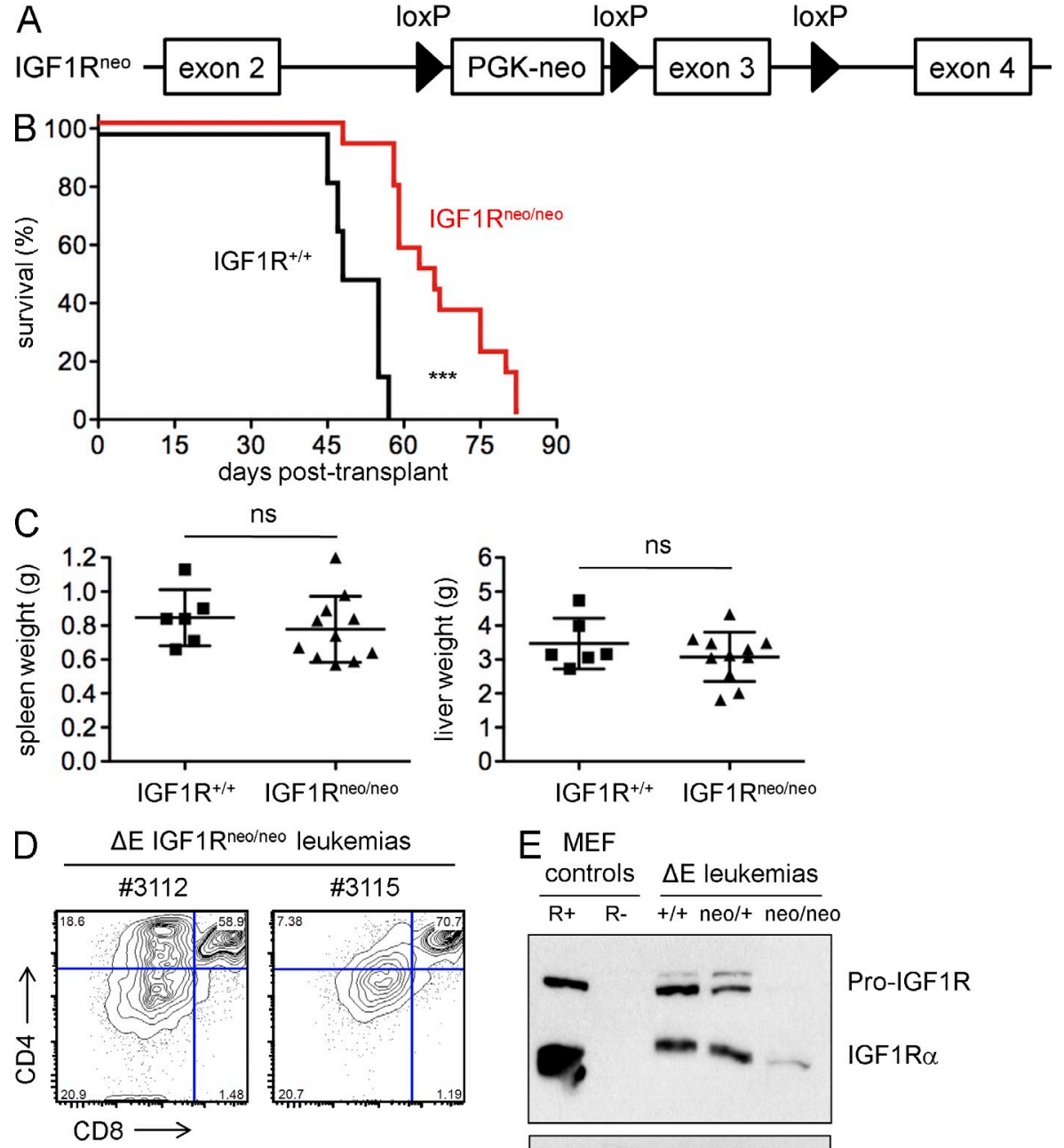

E MEF controls $\triangle \mathrm{E}$ leukemias R+ R- $+/+$ neo/+ neo/neo

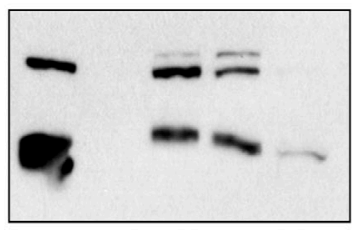

Pro-IGF1R

IGF1R $\alpha$

ERK2 (42kD)
Figure 3. Primary mouse T cell leukemias are generated efficiently by activated Notch1 despite reduced IGF1R expression. (A) Schematic of the IGF1R neo allele. The retained neo cassette within the second intron results in reduced expression of full-length IGF1R protein in IGF1R neo/neo mice (Holzenberger et al., 2000). (B) Survival of mice transplanted with retroviral Notch1 $(\Delta \mathrm{E})$ transduced bone marrow from either WT $($ IGF1R+l+; $n=6)$ or IGF1R hypomorph (IGF1R Reo/neo; $n=14$ ) donor animals. ${ }^{* *}, \mathrm{P}<$ 0.0001 (Log-rank test). (C) Spleen and liver organ weights at necropsy of individual morbid mice transplanted with Notch $1(\Delta \mathrm{E})$ transduced bone marrow from IGF1R $\mathrm{R}^{+++}(n=6)$ and IGF1Rneo/neo $(n=11)$ backgrounds. Error bars indicate standard deviation. (D) Immunophenotypic analysis of representative primary mouse $\Delta \mathrm{E}$ leukemias derived on the IGF1R $\mathrm{R}^{\text {neo/neo }}$ background. (E) Western blot analysis of total IGF1R protein expression in representative primary mouse $\Delta$ E leukemias on IGF1 $\mathrm{R}^{+/+}$, IGF1R neo/+, and IGF1R neo/neo backgrounds. $\mathrm{R}+$ and $\mathrm{R}-$ mouse embryonic fibroblast staining controls and Erk2 loading control are indicated. Data depicted in D and $\mathrm{E}$ are representative of at least seven independent samples.

compared with controls (Fig. S4, A-E). Furthermore, leukemia cells explanted from moribund, untreated animals ( $\sim 8$ wk post-transplant) and cultured with 4-hydroxytamoxifen (4-OHT) in vitro to induce deletion of IGF1R also demonstrated growth arrest and loss of viability (Fig. S4 F). 4-OHT support LIC activity as assayed by serial transplantation in syngeneic/congenic recipients.

\section{Deletion or pharmacologic inhibition of IGF1R prevents disease establishment/progression}

To assess the effect of complete loss of IGF1R in T-ALL cells, we transduced bone marrow from IGF1R neo/neo Rosa26 CreERT mice with Notch1 $(\Delta \mathrm{E})$ retrovirus, followed by transplantation into WT recipient mice. At 4 wk after transplant, peripheral blood was assessed by flow cytometry to confirm engraftment by $\mathrm{GFP}^{+} \mathrm{CD}^{+} \mathrm{CD}^{+}$leukemia cells. Mice were then divided into equivalent control versus treatment groups, and the latter was fed tamoxifen-containing chow $(1 \mathrm{~g} / \mathrm{kg})$ for a 7 -d period to induce deletion of IGF1R. Mice from both groups were then sacrificed, and tissues were harvested. Preliminary results show that tamoxifen-treated mice demonstrate significantly lower levels of disease involvement in all tissues examined (bone marrow, spleen, and thymus), and leukemia cells from tamoxifen-treated animals exhibited lower proliferative and higher apoptotic indices as treatment showed no discernible toxic effects on control IGF1R ${ }^{\text {neo/neo }}$ Rosa $26^{+/+}$leukemia cells. Additionally, preliminary results from mice engrafted with a T-ALL cell line (144CLP) derived from a mouse $\mathrm{Kras}^{\mathrm{G} 12 \mathrm{D}}$ tumor (Chiang et al., 2008) show that treatment with BMS-754807, a potent IGF1R inhibitor currently in clinical development (Carboni et al., 2009), significantly prolonged survival (Fig. S5), thus corroborating the genetic deletion results. Collectively, these data support that abrogation of IGF1R signaling impedes T-ALL cell growth/survival and interferes with disease establishment/progression.

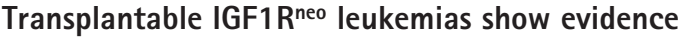 for downstream compensation}

Our observation that a minority of IGF1R neo/neo leukemias is transplantable suggests secondary alterations may be selected for in vivo that compensate for reduced IGF1R signaling. Despite the known frequency of PTEN loss and PIK3CA/ PIK3R 1 mutations in T-ALL (Maser et al., 2007; Palomero et al., 2007; Gutierrez et al., 2009), we were unable to detect 
A

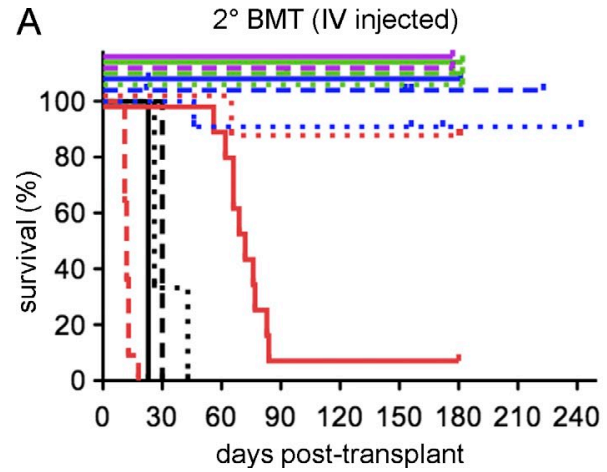

IGF1R $1 /+$

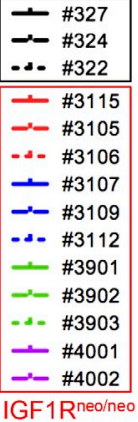

B

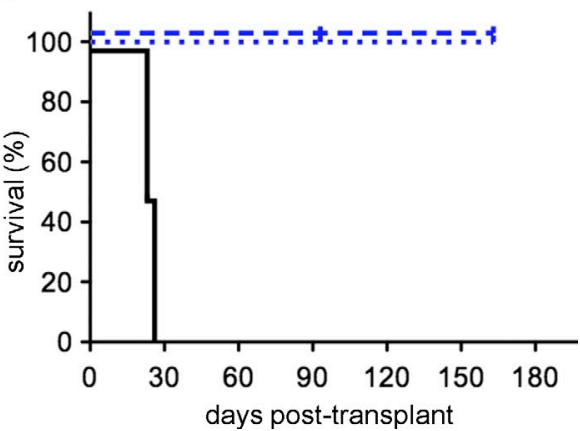

Figure 4. Mouse T cell leukemias with reduced IGF1R expression are defective in serial transplantation. Survival of mice transplanted with primary mouse $\Delta \mathrm{E}$ leukemia cells from either IGF1 $\mathrm{R}^{+/+}$or IGF1R neo/neo backgrounds by i.v. (A) intrafemoral (IF; B) injection route. Each numbered sample represents a different primary leukemia from mice in Fig. 3 B injected into secondary recipients. Raw survival data, including numbers of animals in each cohort, are provided in Table S1. Data depicted are collated from four independent transplantation experiments.

these alterations in any of the transplantable $\Delta \mathrm{E}-\mathrm{IGF} 1 \mathrm{R}^{\text {neo/neo }}$ leukemias (Fig. 5, A and B; and not depicted). We thus considered that enhanced responsiveness to growth factor stimulation could compensate for reduced IGF1R expression. In fact, transplantable leukemias \#3112 and \#3115 demonstrated enhanced pAkt response to serum stimulation as compared with nontransplantable leukemias, though not to the degree exhibited by IGF1R ${ }^{+/+}$cells (Fig. 5 C). We excluded the possibility that IGF1R itself was up-regulated as transplantable IGF1R ${ }^{\text {neo/neo }}$ leukemias remained only minimally responsive to IGF-1, and are comparable to nontransplantable IGF1R ${ }^{\text {neo/neo }}$ leukemias in this regard (Fig. $\left.5 \mathrm{D}\right)$. We also noted the one IGF1R neo/neo leukemia exhibiting very short latency in secondary recipients (\#3105) had unusually high levels of pAkt at steady state (twofold greater than IGF1R ${ }^{+/+}$ cells; Fig. 5 E). The elevated pAkt in these cells was not reduced even after prolonged serum starvation (unpublished data), suggesting the presence of some constitutively activating mutation that confers growth factor independence. In contrast, we have not found similarly compelling evidence
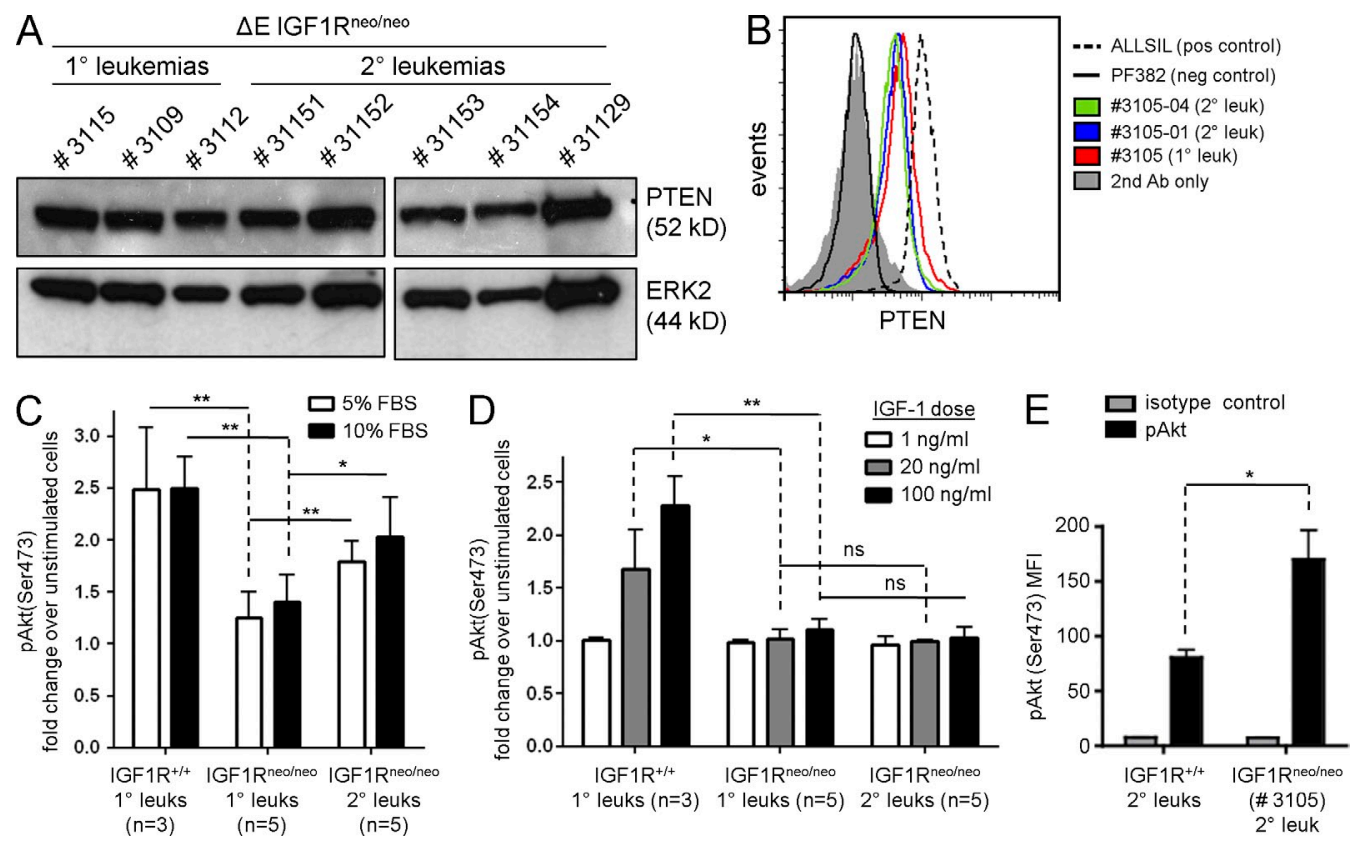

Figure 5. Transplantable clones with reduced IGF1R expression show compensatory PI3K-Akt activation. (A) Western blot and (B) flow cytometric analysis of PTEN protein expression in primary and transplantable secondary $\Delta E-I G F 1 R^{\text {neo }}$ leukemias. (C and D) Akt activation as measured by intracellular phospho-Akt(Ser473) flow cytometry in response to stimulation with FBS (C) or (D) recombinant IGF-1 $\times$ (D) 10 min after 5-h serum starvation. (E) Steady-state level of Akt activation as measured by pAkt(Ser473) in transplantable $\Delta$ E-IGF1R ${ }^{++}$and $\Delta$ E-IGF1R neo (\#3105) leukemias ( $n=3$ independent mice for each cohort). For $C$ and $D$, the five $\Delta E-I G F 1 R^{n e o}$ transplantable clones shown are $(4 \mathrm{x} \# 3115,1 \times \# 3112)$. Error bars indicate standard deviation. ${ }^{*}, \mathrm{P}<0.05 ;{ }^{* *}, \mathrm{P}<0.01$ (Student's $t$ test). Data depicted in $\mathrm{A}$ and $\mathrm{B}$ are representative of at least three independent experiments. Data depicted in $\mathrm{C}-\mathrm{E}$ are representative of two independent experiments and include at least three independent mice per cohort per experiment. 
for hyperactivation of the Ras-Raf-MAPK pathway to explain the unique transplantability of these IGF1R ${ }^{\text {neo/neo }}$ clones (unpublished data). These few examples suggest PI3K-Akt activation may potentially be more important than Ras-RafMAPK signaling in conferring LIC activity; however, further study is needed to clarify this issue.

\section{IGF1R mRNA and protein expression}

\section{is up-regulated by Notch}

To explore mechanisms that may support the high-level IGF1R expression required for LIC activity, we considered a potential role for Notch signaling. Notch has previously been shown to promote activation of PI3K-Akt in developing thymocytes (Ciofani and Zuñiga-Pflucker, 2005), and we noted in our expression profile datasets evidence for upregulation of IGF1R by Notch signaling. More specifically, we performed microarray-based expression profiling of five human T-ALL cell lines (ALLSIL, DND41, HPBALL, KOPTK1, and TALL-1) treated with $\boldsymbol{\gamma}$-secretase inhibitor
(GSI) to inhibit Notch signaling or vehicle control (DMSO). These five cell lines were selected because they undergo growth arrest upon GSI treatment (Weng et al., 2004; Palomero et al., 2007). To control for off-target effects of GSI, we also profiled cell lines that had been retrovirally transduced with ICN1, and then treated with GSI or DMSO. ICN1, the intracellular domain of Notch1, is unaffected by GSI treatment and thus maintains Notch signaling in the presence of GSI (Weng et al., 2003, 2004). Further, because Notch1 induces transcription of c-Myc (Palomero et al., 2006b; Sharma et al., 2006; Weng et al., 2006), which in turn induces transcription of many other genes (Fernandez et al., 2003), we also profiled cells that had been transduced with c-Myc and then treated with GSI or DMSO to segregate Notch targets from c-Myc targets. We identified genes whose expression level most strongly correlated with Notch activity, but not with c-Myc, and noted the conspicuous presence of IGF1R on this list (Table S2) and in other published microarray datasets generated from GSItreated T-ALL cells (Fig. S6; Palomero et al., 2006b).
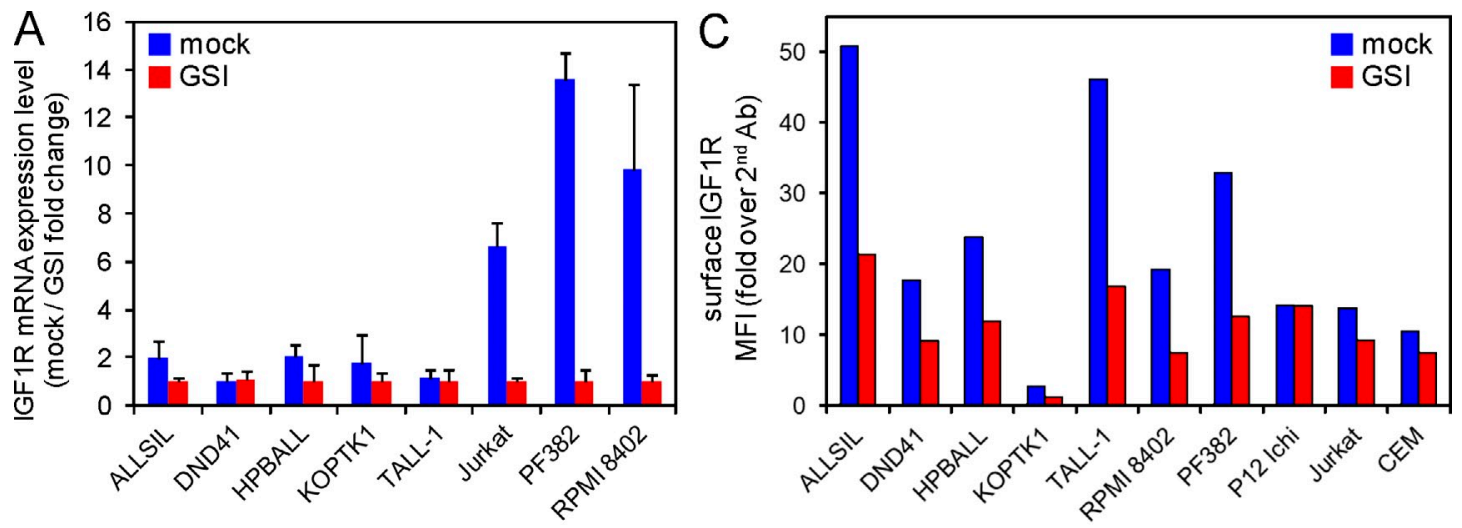

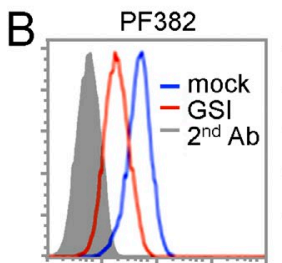

ALLSIL

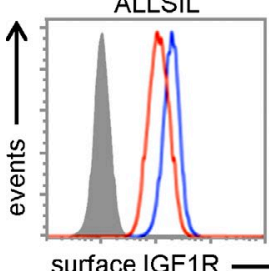

surface IGF1R

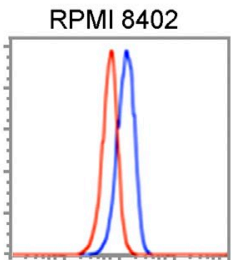

HPBALL

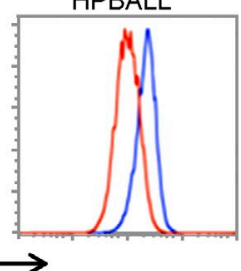

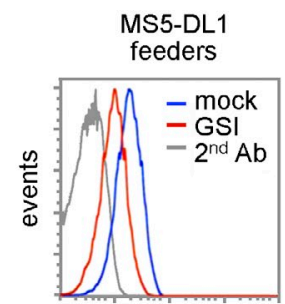

surface IGF1R
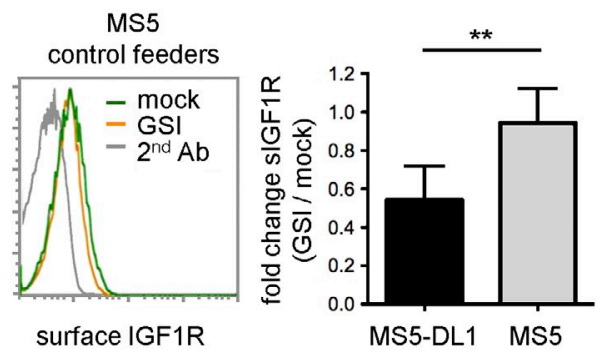

Figure 6. Inhibition of Notch signaling with GSI down-regulates IGF1R expression in human T-ALL cells. (A) qRT-PCR analysis of IGF1R mRNA in human T-ALL cell lines treated in vitro with $\gamma$-secretase inhibitor (GSI) to block Notch signaling versus DMSO vehicle (mock) for 2-10 d. Error bars indicate standard deviation for assays performed in triplicate. (B and C) Flow cytometric analysis of surface IGF1R expression by human T-ALL cell lines treated with GSI versus DMSO vehicle for 6-8 d. Data are representative of multiple replicates. (D) Flow cytometric analysis of surface IGF1R expression by xenograft-expanded primary human T-ALL cells. Cells were cultured on MS5-DL1 feeders to stimulate Notch signaling versus MS5 control feeders and then treated with $1.0 \mu \mathrm{M}$ compound $\mathrm{E}(\mathrm{GSI})$ for 2-4 d to block Notch signaling. Flow histograms for a representative case are depicted on the left, and results from six different patient samples are summarized on the right. Error bars indicate standard deviation. ${ }^{* *}, \mathrm{P}<0.01$ (Student's $t$ test). At least 20,000 gated live events were collected for all flow cytometry assays. 
We also performed a similar expression profiling experiment using the human T-ALL cell line, CUTLL1, which harbors a $\operatorname{TrB}$ /Notch1 fusion gene that drives expression of a form of Notch1 resembling $\Delta \mathrm{E}$ (Palomero et al., 2006a). CUTLL1 cells transduced with empty retrovirus (MigR1) or dominant-negative (DN) MAML1-GFP, a specific Notch inhibitor (Weng et al., 2003; Maillard et al., 2004; Weng et al., 2004), were treated with GSI for 3 d, after which GSI was washed out to create a timed pulse of Notch signaling activity. Expression profiling was done on cells before washout and at 2 and $4 \mathrm{~h}$ after washout to identify likely direct Notch1 target genes. We observed GSI washout up-regulated expression of IGF1R along with other known Notch1 target genes, such as Hes1, Hes4, Hes5, NRARP, and DTX1 in MigRI control cells, and that DN-MAML1-GFP partially or completely abrogated up-regulation of the same set of genes (Fig. S7).

To validate these expression profile data, we performed qRT-PCR for IGF1R mRNA. Notch-dependent T-ALL cell lines (ALLSIL, DND41, HPBALL, KOPTK1, and TALL-1) down-regulated IGF1R mRNA levels up to twofold when treated with GSI, whereas Notch-independent lines (Jurkat, PF382, and RPMI 8402) showed 6-14-fold down-regulation of IGF1R mRNA (Fig. 6 A). GSI blockade also down-regulated IGF1R protein levels 2-3 fold on average, as judged by flow cytometry and Western blotting of human T-ALL cell lines and xenograft-expanded primary samples (Fig. 6, B-D; and Fig. S8). This effect of GSI is likely specific to Notch, as DN-MAML1 also decreased IGF1R protein levels (Fig. 7 A), and the effect of GSI on IGF1R was rescued by retroviral transduction with ICN1 (Fig. 7 B). Conversely, culture of xenograft-expanded primary human T-ALL cells on MS5 stromal cells expressing the Notch ligand DL1, but not MS5 control cells, increased IGF1R levels, whereas no such change was observed for the control marker CD45 (Fig. 7 C). In addition, this effect of DL1 ligand on IGF1R levels was abrogated by treatment with GSI (Fig. 6 D). Thus, these data are consistent with a role for Notch signaling in up-regulation of IGF1R expression in human T-ALL cells.

\section{ICN1/CSL binds to an intronic IGF1R enhancer}

Once cleaved from the plasma membrane by $\gamma$-secretase, ICN1 translocates to the nucleus where it forms a ternary complex on DNA with the DNA-binding factor CSL and the coactivator MAML1 to stimulate transcription of target genes (Aster et al., 2008). To define the regulatory elements through which Notch1 up-regulates target genes in an unbiased fashion, we performed chromatin immunoprecipitation (ChIP)-Seq analysis on the human T-ALL cell line, CUTLL1, using antibodies directed against Notch1 and CSL (Wang et al., 2011). Alignment of sequencing reads from duplicate CSL and Notch1 libraries identified one high-confidence ICN1/CSL-binding site within intron 20 of IGF1R at a position $>250 \mathrm{~kb} \mathrm{3}^{\prime}$ of the proximal promoter (Fig. $8 \mathrm{~A}$ ). The next nearest ICN1/CSL-binding site lies $~ 10.5 \mathrm{Mbp} 5^{\prime}$ of the proximal promoter, making this $3^{\prime}$ binding site the
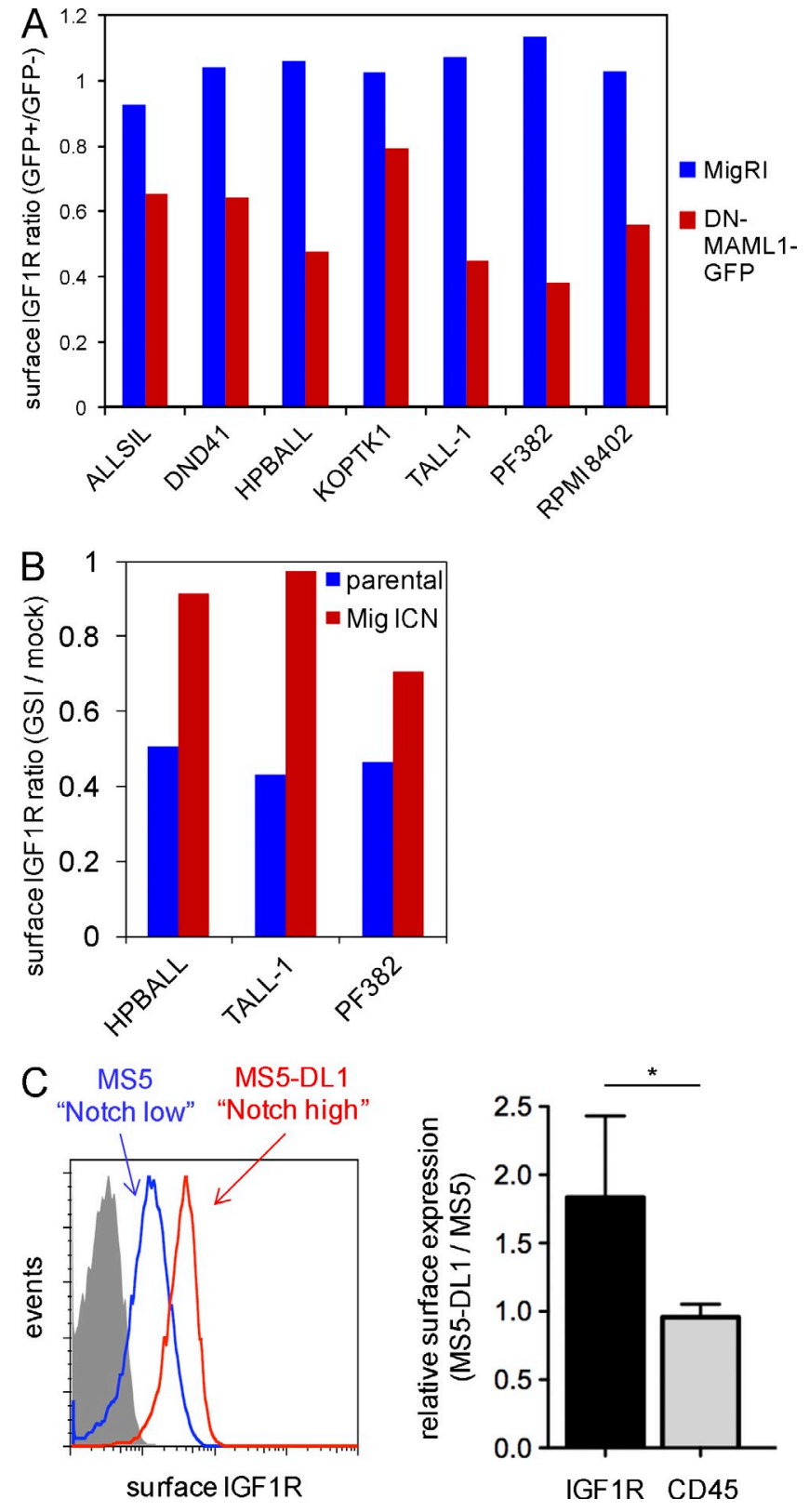

Figure 7. Inhibition of Notch signaling with dominant-negative MAML1 and activation by ICN1 or DL1 ligand confirm IGF1R regulation by Notch. Flow cytometric analysis of surface IGF1R expression. (A) Human T-ALL cell lines were transduced with dominant negative Mastermind-like-1 retrovirus (DN-MAML1-GFP) or empty virus control (MigRI). (B) Human T-ALL cell lines were transduced with ICN retrovirus (Mig ICN) and then treated with $1.0 \mu \mathrm{M}$ compound $\mathrm{E}$ (GSI) for $4 \mathrm{~d}$ (HPBALL and TALL-1) or $8 \mathrm{~d}$ (PF382) to block endogenous Notch signaling or DMSO vehicle (mock). Retrovirally transduced cells in $A$ and $B$ were discriminated from nontransduced cells by gating for GFP. Data depicted in A and B are representative of multiple replicates. (C) Xenograftexpanded primary human T-ALL cells were cultured in vitro on MS5-DL1 feeders to stimulate Notch signaling versus control MS5 feeders. CD45 expression levels were also assessed simultaneously with IGF1R by flow cytometry. Flow histograms for a representative case are depicted on the left, and results from six different patient samples are summarized on the right. Error bars indicate standard deviation. ${ }^{*}, \mathrm{P}<0.05$ (Student's $t$ test). At least 20,000 live events were collected within each gate for all flow cytometry assays. 
only likely candidate response element for Notch1 regulation. Motif analysis using recently developed algorithms derived from protein-binding microarrays (Del Bianco et al., 2010) showed that the center of the region under the ICN1/ CSL-binding peak contains high (CATGGGAA) and moderate (GCTGAGAA) affinity CSL sites oriented head-to-head and separated by a 17-bp spacer (Fig. 8 B). This architecture is typical of a sequence-paired site, a special type of Notch response element first identified in Drosophila enhancer of split (E[spl]) locus that is present in mammalian E(spl) homologues such as Hes1 (Jarriault et al., 1995) and other genes such as preT $\alpha$ (Liu et al., 2010). Loading of ICN1 onto this site was confirmed by ChIP/quantitative PCR (qPCR) analyses, performed on CUTLL1 cells and two additional human T-ALL cell lines, HPBALL and KOPTK1 (Fig. 8 C). In addition, GSI treatment of CUTLL1 cells depleted both CSL and ICN1 from this site (in line with work from Bray's group indicating that ICN stabilizes CSL interactions with DNA; Krejcí and Bray, 2007), and GSI washout resulted in rapid reloading, indicating that ICN1/CSL occupancy is dynamic (Fig. 8 D).

The distant location of the putative ICN1/CSL response element in IGF1R suggested that it represents an enhancer. In support of this possibility, additional ChIP analyses documented recruitment of the histone acetyltransferases CREBbinding protein $(\mathrm{CBP})$ and $\mathrm{p} 300$, as well as RNA polymerase II, to this site (Fig. S9 A; Hatzis and Talianidis, 2002; Wang et al., 2005). Moreover, we observed enrichment of histone H3K4 mono- and dimethylation chromatin marks (characteristic of enhancers) relative to $\mathrm{H} 3 \mathrm{~K} 4$ trimethylation marks (a feature of promoters; Heintzman et al., 2007), and low levels of the repressive trimethyl histone H3K27 chromatin mark (Fig. S9 B; Kirmizis et al., 2004). Finally, additional ChIP-Seq data showed a local decrease in H3K4 methylation at the precise site of the intronic IGF1R sequencepaired site, indicating that this site lies in accessible chromatin that has been depleted of nucleosomes (Fig. S9 C). Collectively, these data support the presence of an intronic
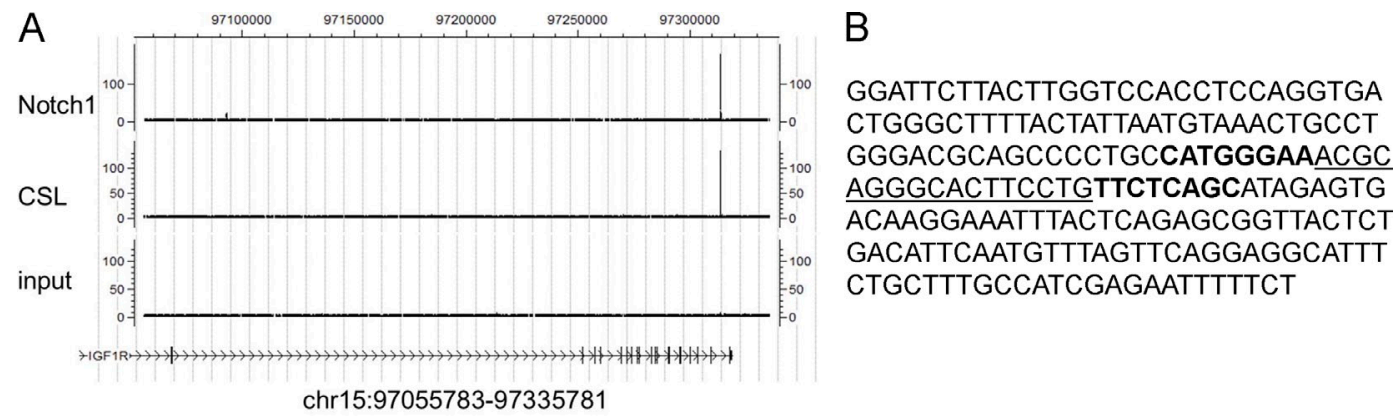

chr15:97055783-97335781
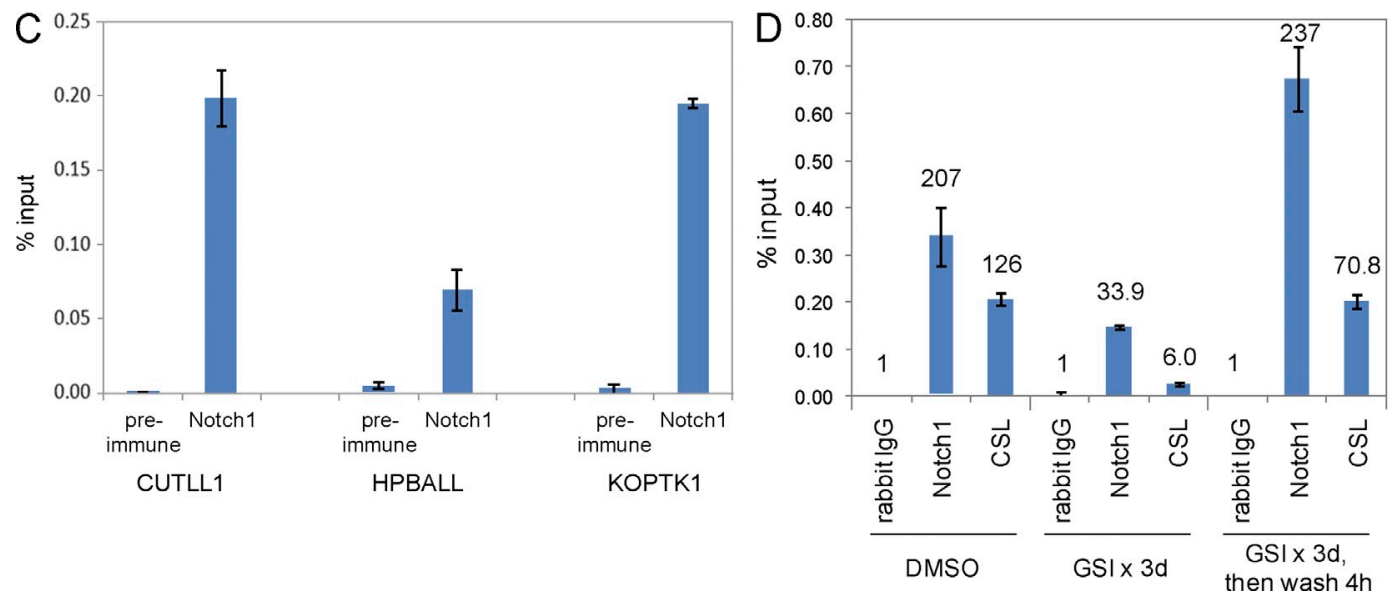

Figure 8. ICN1/CSL binds dynamically to a site within intron 20 of human IGF1R. (A) Alignment of sequencing reads over intron 20 of the IGF1R locus from ChIP libraries prepared from the human T-ALL cell line, CUTLL1, with antibodies specific for Notch1 and CSL as compared with input cells. (B) Genomic DNA sequence from human IGF1R intron 20 (NT_010274.17: 14461410-14461610) with sequence-paired ICN1/CSL binding sites highlighted in bold and 17-bp spacer underlined. (C) ChIP/qPCR analysis of IGF1R intron 20 from three different human T-ALL cell lines using a Notch1-specific antibody as compared with preimmune antiserum. (D) ChIP/qPCR analysis of IGF1R intron 20 from CUTLL1 cells using antibodies specific for Notch1 and CSL compared with control rabbit lgG. Cells were treated with GSI for $3 \mathrm{~d}$ to block Notch signaling (GSI x 3d) versus DMSO vehicle (DMSO). GSI was washed out, and cells were harvested $4 \mathrm{~h}$ later (GSI $\times 3 \mathrm{~d}$, then wash $4 \mathrm{~h}$ ). Quantitation of immunoprecipitated DNA is expressed relative to input DNA (\% input). Error bars indicate standard deviation for qPCR assays performed in triplicate. Numbers above bars in D indicate relative enrichment over control. ChIP libraries were prepared in duplicate, and local ChIP/qPCR analyses were performed twice. Representative results are shown. 
Notch1-responsive enhancer in human IGF1R that is active in human T-ALL cells.

\section{Physiological relevance of Notch-induced up-regulation of IGF1R}

Notch signaling is likely one of several factors that influence IGF1R expression in T-ALL, as Notch inhibition results in only a two- to threefold decrease in surface IGF1R expression, on average. To assess whether this two- to threefold change in IGF1R protein levels has a significant effect on downstream signaling, we measured levels of intracellular phosphorylated Akt (pAkt) after pulsing serum-starved leukemia cells with recombinant IGF-1. We observed GSItreated cells to be $\sim 20$-fold less responsive to IGF-1 than vehicle-treated control cells (Fig. 9 A). Although some of this effect is presumably caused by GSI effects on IGF1R expression, it has also been reported that Notch represses PTEN via HES-1 (Palomero et al., 2007), which could also impact the pAkt response. Indeed, GSI treatment induced PTEN expression in HPBALL cells; however, there was no detectable change in ALLSIL or DND41 cells (Fig. 9 B). Accordingly, restoration of IGF1R expression in GSI-treated cells by retroviral transduction only partially rescued the pAkt response to IGF1 in HPBALL cells (Fig. 9 C), whereas rescue was complete in PTEN null PF382 cells (Fig. 9 D; Palomero et al., 2007). Importantly, we confirmed retroviral IGF1R restored expression in GSI-treated cells to levels comparable to parental cells. Thus, although Notch inhibition can affect both IGF1R and PTEN expression, Notch contributes to supporting IGF1R expression at high levels, thereby allowing T-ALL cells to respond more robustly to ambient levels of IGF-1/2.

\section{DISCUSSION}

We have presented data showing that IGF1R mediates important growth/survival signals in T-ALL cells, and that although moderate levels of signaling are adequate for maintenance of the bulk cell population, high levels are required for maintenance of LIC activity as indicated by serial transplantation assay. The effect of reduced IGF1R signaling on disease transplantability could be caused by (a) a quantitative decrease in the number of leukemia stem cells; (b) a qualitative defect in self-renewal, engraftment ability, and/or immune resistance of leukemia stem cells; or (c) a reduced
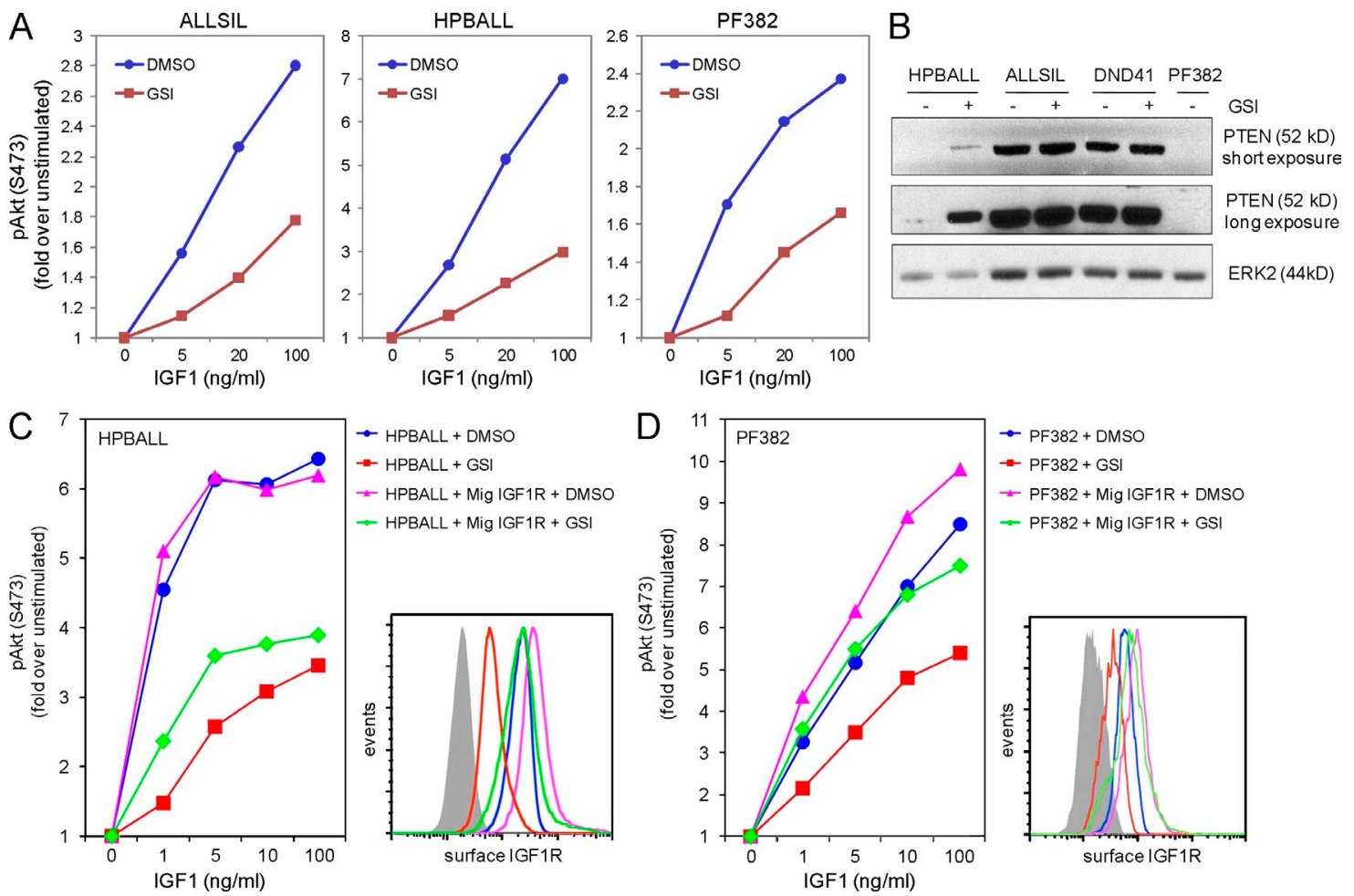

Figure 9. Notch-induced IGF1R expression enhances PI3K-Akt signaling in response to IGF1. (A) Flow cytometric analysis of intracellular phospho-Akt levels. Cells were treated with GSI versus DMSO vehicle for 6-8 d, serum starved overnight, and then pulsed with recombinant IGF1 for 10 min before assay. (B) Western blot analysis of PTEN protein expression in cells treated with GSI versus mock for $4 \mathrm{~d}$. (C and D) Flow cytometric analysis for intracellular phospho-Akt levels (left) and surface IGF1R levels (right). Cells were retrovirally transduced with Mig IGF1R, treated with GSI versus DMSO vehicle for $4 d$, serum starved overnight, and then pulsed with recombinant IGF1 for 10 min before phospho-Akt assay. Transduced versus nontransduced cells within the same culture were distinguished by gating for GFP. Surface IGF1R expression level was also assessed by flow cytometry immediately before stimulation with IGF1. Filled grey histograms represent second antibody staining controls. At least 20,000 events were collected within each gate for all flow cytometry assays. Data depicted are representative of at least two independent experiments. 
probabilistic likelihood of engraftment/propagation of bulk leukemia cells. Notably, the last possibility does not presume the existence of leukemia stem cells in this model; however, we have generated data that supports that Notch T-ALLs indeed contain bona fide leukemia stem cells (unpublished data). Nonetheless, further studies will be required to distinguish between these possibilities.

We have also shown that Notch directly up-regulates IGF1R expression in human T-ALL cells to an extent that substantially enhances their sensitivity to ambient ligand. It is worthwhile to note that we have found no evidence to support that Notch regulates IGF1R in mouse T-ALL cells. In fact, the sequence-paired ICN1/CSL-binding site within intron 20 of human IGF1R is not conserved in the mouse, suggesting that sequence divergence has decoupled this point of interaction between the Notch1 and IGF1R pathways. This is perhaps not surprising given that $40-90 \%$ of transcription factor binding events are not conserved between mouse and human (Odom et al., 2007), underscoring the importance of studying human cells and animal models in parallel.

The existence of leukemia stem cells in human T-ALL is supported by xenograft transplantation assays (Cox et al., 2007; Chiu et al., 2010; Gerby et al., 2011) and also in mouse models of T-ALL by transplantation into SCID or Rag1 ${ }^{-1-}$ immunocompromised recipients (Guo et al., 2008; Tremblay et al., 2010). The precise cellular compartment most enriched for LIC activity appears to vary from patient to patient and between different animal models, and likely depends on the particular complement of genetic alterations present in the leukemic clone and the particular transplant recipient used (Cox et al., 2007; Quintana et al., 2008; Chiu et al., 2010; Gerby et al., 2011). Nonetheless, it is interesting to note that Notch signaling has been shown to contribute to human T-ALL LIC activity in nonobese diabetic (NOD)/Scid transplantation assays (Armstrong et al., 2009). As Notch signaling is mediated through transcriptional activation, identification of downstream target genes has received much attention. In several such studies, c-Myc has been identified as a direct transcriptional target of Notch1 (Palomero et al., 2006b; Sharma et al., 2006; Weng et al., 2006), and may constitute part of a self-renewal genetic program similar to that demonstrated in induced pluripotent stem cells (Takahashi and Yamanaka, 2006; Takahashi et al., 2007). Notch may also repress PTEN (Palomero et al., 2007), and thus potentiate $\mathrm{PI} 3 \mathrm{~K}-\mathrm{Akt} / \mathrm{mTOR}$ signaling which may also promote LIC activity (Yilmaz et al., 2006).

Most prior studies have focused on signaling via IL-7 (Dibirdik et al., 1991; Barata et al., 2004a,b,c, 2005; GonzálezGarcia et al., 2009; Shochat et al., 2011; Silva et al., 2011) or mutational activation of intermediates in the PI3K-Akt pathway (Palomero et al., 2007; Gutierrez et al., 2009). The importance of PI3K-Akt activation in T-ALL is underscored by multiple studies showing that PI3K-Akt/mTOR inhibitors block growth/survival of T-ALL cells (Avellino et al., 2005; Wei et al., 2006; Palomero et al., 2007; Chiarini et al., 2009; Cullion et al., 2009). Notably, our observation that complete inhibition of IGF1R signaling blocks growth/survival of bulk leukemia cells confirms previous results with PI3K-Akt/ mTOR inhibitors, and further illustrates that IGF1-dependent activation contributes in a substantive way to net PI3K-Akt signaling output. Perhaps most intriguing, however, is our observation that moderately decreased IGF1R signaling (as modeled by IGF1R ${ }^{\text {neo/neo }}$ leukemias) results in selective loss of LIC activity, yet leaves the growth and survival of bulk cells relatively unaffected. These findings suggest that LICs in T-ALL may be uniquely sensitive to inhibition of IGF1R signaling, and raise the possibility that pharmacologic IGF1R inhibitors now in clinical development could, in combination with standard regimens, enhance initial response to therapy and reduce rates of disease relapse. Importantly, normal hematopoietic stem cell function appears not to be affected in IGF1R ${ }^{\text {neo/neo }}$ mice (unpublished data), suggesting a therapeutic window exists in which IGF1R inhibitors block LIC activity yet have minimal effects on normal hematopoiesis.

\section{MATERIALS AND METHODS}

Mice. The IGF1R neo line contains a PGK-neo-poly(A) expression cassette integrated within the second intron, resulting in decreased expression of full-length IGF1R (Holzenberger et al., 2000). The IGF1R ${ }^{\text {neo }}$ allele has been backcrossed onto the C57BL/6 background for over 20 generations. Rosa26 CreERT mice were obtained from The Jackson Laboratory. All transplants involving mouse cells were performed using C57BL/6J (B6) or B6(Cg) $-T y r^{-2 J / J}$ ("B6-albino") recipient mice (The Jackson Laboratory). Transplants involving human cells were performed using NOD-Scid/ IL2R $\gamma \mathrm{c}^{-1-}$ recipient mice. Animals were housed under specific pathogenfree conditions at the BC Cancer Agency or Dana-Farber Cancer Institute animal facilities, and experimental studies performed under protocols approved by the University of British Columbia or Dana-Farber Institutional Review Boards, respectively. IGF1R genotyping was performed by multiplex assay with primers YNex (5'-CCATGGGTGTTA AATGTTAATGGC-3'), YNvl (5'-ATGAATGCTGGTGAGGGTTGTCTT-3') and YNmt2 (5'-ATCTTGGAGTGGTGGGTCTGTTTC-3'), as previously described (Leneuve et al., 2001). Rosa26 genotyping was performed with primers RcreFW (5'-AAAGTCGCTCTGAGTTGTTAT-3') and RcreRV (5'-GCGAAGAGTTTGTCCTCAACC-3') for the CreERT allele, and with RwtFW (5'-GCACTTGCTCTCCCAAAGTC-3') and RwtRV $\left(5^{\prime}\right.$-GGCGGATCACAAGCAATAAT-3') for the WT allele.

Plasmids. Retroviral vectors all used the MSCV-IRES-GFP (Mig) backbone. Mig ICN1, Mig $\triangle \mathrm{E}$, and MSCV-DN-MAML1-GFP have been described previously (Aster et al., 1997; Weng et al., 2003). Mig IGF1R was generated by subcloning a 4.2-kb NotI-BamHI fragment containing the human IGF1R cDNA from pBABE-bleo IGF1R (Addgene) into the Mig vector.

Retroviral transduction/bone marrow transplantation. High titer, replication-defective retroviral supernatants were produced by transient transfection of PlatE cells as described previously (Medyouf et al., 2010). MSCV-based retroviral expression vectors included IRES-GFP cassettes for fluorescent tagging of transduced cells. Retroviral transduction of 5-fluorouracil-treated or lineage-depleted (CD4, CD8, CD11b, B220, Ter119, and Gr1) bone marrow cells was performed as described previously (Medyouf et al., 2010). For primary transplants, WT C57BL/6 recipient mice were lethally irradiated (810 rads), and then injected intravenously with 30,00045,000 transduced $\mathrm{GFP}^{+}$cells along with a minimum of $10^{5}$ syngeneic whole bone marrow cells to ensure hematopoietic reconstitution. For serial transplants, 0.5-1.0 $\times 10^{6} \mathrm{GFP}^{+}$leukemia cells (from spleen or bone marrow of a moribund leukemic mouse) were injected into the tail vein (i.v.) or intramedullary 
space of the femur (intrafemoral [IF]) of nonirradiated C57BL/6 recipients. We define LIC activity here as the ability to produce aggressive disease in syngeneic/congenic secondary recipients under these transplant conditions within $20 \mathrm{wk}$.

Human leukemia samples. Cryopreserved lymphoblast samples were provided by collaborating institutions. Primary samples were obtained at initial diagnosis with informed consent from patients or their legal guardians or as discarded pathological material under approved Institutional Review Board protocols at the Karmanos Cancer Institute, Hôpital Armand-Trousseau, Hopital Saint-Louis, BC Cancer Agency, and BC Children's and Women's Hospital following guidelines established by the Declaration of Helsinki. Expansion of primary human T-ALL cells in irradiated NOD-Scid/IL2R $\gamma \mathrm{c}^{-/}$ mice has been described previously (Medyouf et al., 2010).

In vitro culture of primary T-ALL cells. Primary human T-ALL cells were cultured on MS5-DL1/MS5 stromal feeder cells as previously described (Medyouf et al., 2010). Primary mouse T-ALL cells were cultured without feeders in complete media with supplemental cytokines.

Cell lines. IGF1R knockout mouse embryo fibroblasts (R-cells) that were engineered to re-express human IGF1R $(\mathrm{R}+)$ were a gift from P. Sorensen (BC Cancer Agency, Vancouver, British Columbia, Canada). All established T-ALL cell lines were grown in RPMI 1640 medium supplemented with 10\% FCS, $1 \mathrm{mM}$ sodium pyruvate, $2 \mathrm{mM} \mathrm{L}$-glutamine, and antibiotics.

Ligand stimulation assay. Leukemia cells were serum starved overnight, and then stimulated for $10 \mathrm{~min}$ with either recombinant IGF-1 (PeproTech), recombinant insulin (Sigma-Aldrich), or fetal calf serum (Invitrogen), at indicated doses. Cells were then fixed immediately by addition of formaldehyde (Electron Microscopy Services) to $1.5 \%$, and permeabilized with ice-cold methanol for at least $1 \mathrm{~h}$ before analysis by flow cytometry.

In vitro proliferation/apoptosis assays. Cells were pulsed with $10 \mu \mathrm{M}$ $\mathrm{BrdU}$ for $1 \mathrm{~h}$ at $37^{\circ} \mathrm{C}$, and then fixed/stained with anti-BrdU antibody according to manufacturer instructions (FITC or APC BrdU Flow kit; BD) and analyzed by flow cytometry with gating for mouse and human leukemia cells by GFP- and hCD45-positive events, respectively. Cell growth was also measured by CellTiter-Blue assay (Promega) or Ki67-Alexa Fluor 647/ Hoechst staining (BD Biosciences). Apoptotic cells were identified by staining with Annexin V-FITC/7-aminoactinomycin or active caspase-3-PE (BD). Cell viability was assessed by propidium iodide exclusion and analysis by flow cytometry.

Antibody reagents. Antibodies directed against the following proteins were used: IGF1R $\alpha$ (sc-712, Santa Cruz Biotechnology), PTEN (Y184, Abcam), and ERK2 (sc-154, Santa Cruz Biotechnology) for Western blots, and hCD45 (eBioscience), CD4 (L3T4; eBioscience), CD8a (53-6.7, BioLegend), IGF1Ra ( $\alpha$ IR3; EMD), and P-AKT (S473; Cell Signaling Technology) for flow cytometry.

Flow cytometry. Acquisition was performed on FACSCalibur or LSRII cytometers (BD) and data analyzed using Flowjo software (Tree Star, Inc.).

Drugs. IGF1R inhibitors BMS-536924 and BMS-754807 were obtained under Material Transfer Agreement from the manufacturer. BMS-536924 was resuspended in DMSO at $10 \mathrm{mM}$, then serially diluted in Hank's Balanced Salt Solution (Invitrogen) before addition to culture media. BMS754807 was resuspended in PEG400: $\mathrm{H}_{2} \mathrm{O}$ (80:20 by volume) at $5 \mathrm{mg} / \mathrm{ml}$ final concentration before administration to mice. An azide-free preparation of $\alpha$ IR 3 antibody was used for IGF1R blocking studies (EMD). $\gamma$-Secretase inhibitor XXI (compound E) was used at $1.0 \mu \mathrm{M}$ final concentration for all studies (EMD). GSI washout was performed by washing cells twice with prewarmed, complete culture medium. For induction of CreERT activity in vivo, $1 \mathrm{~g}$ tamoxifen (Sigma-Aldrich) was admixed per $1 \mathrm{~kg}$ mouse chow
(Altromin) and mice were allowed to feed ad libitum. For induction of CreERT activity in vitro, 4-OHT (Sigma-Aldrich) was dissolved in ethanol and added to culture media at $50 \mathrm{nM}$ final concentration.

Expression profiling. Total RNA was isolated by TRIzol (Invitrogen) extraction or RNeasy Mini kit (QIAGEN) and submitted to the McGill University/Génome Québec Innovation Centre or Harvard Medical School Biopolymers Core for expression profiling using Affymetrix HG-U133 Plus 2.0 GeneChips. Data were analyzed using dChip software (Schadt et al., 2001). Microarray data are available from the Gene Expression Omnibus accession no. GSE29959.

Quantitative real-time PCR. Total RNA was extracted after cell lysis in TRIzol reagent (Invitrogen). First-strand cDNA was generated by reverse transcription with SuperScript III (Invitrogen) using a mix of random 15-mer and anchored oligo(dT)20+1 primers, and then amplified using Platinum SYBR Green qPCR SuperMix-UDG (Invitrogen) and the following specific primer sets: hIGF1R forward 5'-ACTTACTCGGACGTCTGGTCCTTC-3', hIGF1R reverse 5'-ATCTTGGGGTTATACTGCCAGCAC-3' for IGF1R, and hActB RT5 5'-CGCGAGAAGATGACCCAGAT-3'plus hActB RT3 5'-GAT AGC ACA GCC TGG ATA GCA AC- 3 ' for $\beta$-actin. Each sample was assayed in triplicate using a Dyad Disciple thermal cycler equipped with Chromo4 optical head (Bio-Rad Laboratories). Expression levels were calculated by the $\Delta \Delta \mathrm{Ct}$ method with normalization to $\beta$-actin.

ChIP. ChIP was performed with the ChIP Assay kit (Millipore). In brief, cells were cross-linked with $1 \%$ formaldehyde for $10 \mathrm{~min}$ at $37^{\circ} \mathrm{C}$, lysed in $1 \%$ SDS, and $10 \mathrm{mM}$ EDTA, $50 \mathrm{mM}$ Tris, $\mathrm{pH} 8.1$, and then sonicated to obtain DNA fragments from 200-600 bp. Chromatin was then immunoprecipitated with the following antibodies: Notch1(Tc; Aster et al., 1997), CSL (gift from E. Kieff, Brigham and Women's Hospital, Boston, MA), H3K4me1 (ab8895; Abcam), H3K4me2 (07-030; Millipore), H3K4me3 (07-745; Millipore), CBP (ab10489; Abcam), p300 (sc-585; Santa Cruz Biotechnology, Inc.), RNA pol2 (05623B; Millipore), and mouse $\operatorname{IgG}$ (12-371; Millipore) as control. After overnight incubation with antisera at $4^{\circ} \mathrm{C}$, immunoprecipitated chromatin was captured with Protein A-agarose beads, washed, and eluted. After reversal of cross-links, DNA was purified using the QIAquick PCR purification kit (QIAGEN). Input control DNA was also prepared in parallel, omitting the immunoprecipitation steps. Primers used for qPCR after ChIP were as follows: IGF1Rchip forward 5'-GGTGGGTGAGGGAGAGCGGT-3' and IGF1Rchip reverse 5'-GGCTGCGTCCCAGGCAGTTT-3'.

ChIP-Seq and data analysis. ChIP-Seq libraries were prepared according to the Illumina ChIP DNA library preparation kit. After addition of adaptors, libraries were amplified by 18 cycles of PCR, size selected (150-250 bp) by electrophoresis, and purified using a QIAGEN gel extraction kit. After quality control testing on an Agilent 2100 Bioanalyzer, the library was subjected to deep sequencing using an Illumina Genome Analyzer II in the Harvard Medical School Biopolymers Core facility. Sequencing reads were aligned to human genome build hg18 and analyzed using CisGenome (Ji et al., 2008). One-sample and two-sample analyses were performed using $100-\mathrm{bp}$ windows and reads of $>10 \mathrm{bp}$.

Online supplemental material. Fig. S1 shows Akt response to stimulation with IGF1 and insulin and effects of BMS-536924 inhibitor in T-ALL cells. Fig. S2 shows effects of the BMS-536924 inhibitor on T-ALL cell growth and viability in vitro. Fig. S3 shows resistance to growth inhibition by IGF1R blocking antibody correlates with reduced surface IGF1R expression. Fig. S4 shows effects of IGF1R deletion on T-ALL development in vivo and cell growth/viability in vitro. Fig. S5 demonstrates in vivo efficacy of the IGF1R inhibitor BMS-754807 in a mouse T-ALL model. Fig. S6 shows that IGF1R is a Notch target gene in an independent expression profiling dataset. Fig. S7 shows IGF1R is a Notch target gene in the human T-ALL cell line, CUTLL1. Fig. S8 shows Western blot analysis 
of total IGF1R expression after GSI treatment of human T-ALL cell lines. Fig. S9 shows chromatin modification marks over the human IGF1R locus in the vicinity of the Notch/CSL binding site. Table S1 shows survival data for all secondary, tertiary, and quarternary transplant experiments. Table S2 lists genes whose mRNA expression level decreases most after inhibition of Notch signaling. Online supplemental material is available at http://www .jem.org/cgi/content/full/jem.20110121/DC1.

We thank Amina Kariminia (BC Children's Hospital, Vancouver) for sample preparation, Drs. Kirk Schultz (BC Children's Hospital, Vancouver), Larry H. Matherly (Karmanos Cancer Institute, Detroit), Paola Ballerini (Hôpital Armand-Trousseau, Paris), and Thierry Leblanc (Hopital Saint-Louis, Paris) generously contributed human T-ALL samples.

This work was funded by grants from the Canadian Cancer Society Research Institute/Terry Fox Foundation, US National Cancer Institute (K22CA112538, P01CA119070), Leukemia and Lymphoma Society of Canada, Lymphoma Foundation Canada, Cancer Research Society, and Agence Nationale de la Recherche (NT05-3 42491). H. Medyouf is supported by a Human Frontier Science Program Fellowship. J.C. Aster is supported by grants from the Leukemia and Lymphoma Society and the William Lawrence Foundation. A.P. Weng is a Michael Smith Foundation for Health Research Scholar.

J. Carboni and M. Gottardis are employees of Bristol-Myers Squibb Company. The remaining authors have no competing interests to declare.

Author contributions: H. Medyouf designed and performed experiments, analyzed data, and wrote the manuscript. S. Gusscott, H. Wang, C. Wai, and O. Nemirovsky performed experiments. J. Carboni and M. Gottardis developed and provided the BMS inhibitor compounds. A. Trumpp, F. Pflumio, M. Pollak, and M. Holzenberger provided reagents and resources and discussed results. J. Tseng and A. Kung designed and performed in vivo experiments with BMS-754807. J. Aster designed ChIP experiments, analyzed data, and discussed results. A. Weng supervised the project, designed and performed experiments, analyzed data, and wrote the manuscript.

\section{Submitted: 17 January 2011}

Accepted: 12 July 2011

\section{REFERENCES}

Armstrong, F., P. Brunet de la Grange, B. Gerby, M.C. Rouyez, J. Calvo, M. Fontenay, N. Boissel, H. Dombret, A. Baruchel, J. Landman-Parker, et al. 2009. NOTCH is a key regulator of human T-cell acute leukemia initiating cell activity. Blood. 113:1730-1740. doi:10.1182/blood-2008-02-138172

Aster, J.C., E.S. Robertson, R.P. Hasserjian, J.R. Turner, E. Kieff, and J. Sklar. 1997. Oncogenic forms of NOTCH1 lacking either the primary binding site for RBP-Jkappa or nuclear localization sequences retain the ability to associate with RBP-Jkappa and activate transcription. J. Biol. Chem. 272:11336-11343. doi:10.1074/jbc.272.17.11336

Aster, J.C., W.S. Pear, and S.C. Blacklow. 2008. Notch signaling in leukemia. Annu.Rev.Pathol.3:587-613.doi:10.1146/annurev.pathmechdis.3.121806 .154300

Avellino, R., S. Romano, R. Parasole, R. Bisogni, A. Lamberti, V. Poggi, S. Venuta, and M.F. Romano. 2005. Rapamycin stimulates apoptosis of childhood acute lymphoblastic leukemia cells. Blood. 106:1400-1406. doi:10.1182/blood-2005-03-0929

Barata, J.T., V.A. Boussiotis, J.A. Yunes, A.A. Ferrando, L.A. Moreau, J.P. Veiga, S.E. Sallan, A.T. Look, L.M. Nadler, and A.A. Cardoso. 2004a. IL-7-dependent human leukemia T-cell line as a valuable tool for drug discovery in T-ALL. Blood. 103:1891-1900. doi:10.1182/ blood-2002-12-3861

Barata, J.T., T.D. Keenan, A. Silva, L.M. Nadler,V.A. Boussiotis, and A.A. Cardoso. 2004b. Common gamma chain-signaling cytokines promote proliferation of T-cell acute lymphoblastic leukemia. Haematologica. 89:1459-1467.

Barata, J.T., A. Silva, J.G. Brandao, L.M. Nadler, A.A. Cardoso, and V.A. Boussiotis. 2004c. Activation of PI3K is indispensable for interleukin 7-mediated viability, proliferation, glucose use, and growth of $\mathrm{T}$ cell acute lymphoblastic leukemia cells. J. Exp. Med. 200:659-669. doi:10 $.1084 / \mathrm{jem} .20040789$
Barata, J.T., A.A. Cardoso, and V.A. Boussiotis. 2005. Interleukin-7 in T-cell acute lymphoblastic leukemia: an extrinsic factor supporting leukemogenesis? Leuk. Lymphoma. 46:483-495. doi:10.1080/ 10428190400027852

Bendall, S.C., M.H. Stewart, P. Menendez, D. George, K. Vijayaragavan, T. Werbowetski-Ogilvie, V. Ramos-Mejia, A. Rouleau, J. Yang, M. Bossé, et al. 2007. IGF and FGF cooperatively establish the regulatory stem cell niche of pluripotent human cells in vitro. Nature. 448:10151021. doi:10.1038/nature06027

Carboni, J.M., M. Wittman, Z. Yang, F. Lee, A. Greer, W. Hurlburt, S. Hillerman, C. Cao, G.H. Cantor, J. Dell-John, et al. 2009. BMS-754807, a small molecule inhibitor of insulin-like growth factor-1R/IR. Mol Cancer Ther. 8:3341-3349. doi:10.1158/1535-7163.MCT-09-0499

Chiang, M.Y., L. Xu, O. Shestova, G. Histen, S. L'heureux, C. Romany, M.E. Childs, P.A. Gimotty, J.C. Aster, and W.S. Pear. 2008. Leukemiaassociated NOTCH1 alleles are weak tumor initiators but accelerate K-ras-initiated leukemia. J. Clin. Invest. 118:3181-3194. doi:10.1172/ JCI35090

Chiarini, F., F. Falà, P.L. Tazzari, F. Ricci, A. Astolfi, A. Pession, P. Pagliaro, J.A. McCubrey, and A.M. Martelli. 2009. Dual inhibition of class IA phosphatidylinositol 3-kinase and mammalian target of rapamycin as a new therapeutic option for T-cell acute lymphoblastic leukemia. Cancer Res. 69:3520-3528. doi:10.1158/0008-5472.CAN-08-4884

Chiu, P.P., H. Jiang, and J.E. Dick. 2010. Leukemia-initiating cells in human T-lymphoblastic leukemia exhibit glucocorticoid resistance. Blood. 116:5268-5279. doi:10.1182/blood-2010-06-292300

Ciofani, M., and J.C. Zúñiga-Pflücker. 2005. Notch promotes survival of pre-T cells at the beta-selection checkpoint by regulating cellular metabolism. Nat. Immunol. 6:881-888. doi:10.1038/ni1234

Cox, C.V., H.M. Martin, P.R. Kearns, P. Virgo, R.S. Evely, and A. Blair. 2007. Characterization of a progenitor cell population in childhood T-cell acute lymphoblastic leukemia. Blood. 109:674-682. doi:10.1182/ blood-2006-06-030445

Cullion, K., K.M. Draheim, N. Hermance, J. Tammam, V.M. Sharma, C. Ware, G. Nikov, V. Krishnamoorthy, P.K. Majumder, and M.A. Kelliher. 2009. Targeting the Notch1 and mTOR pathways in a mouse T-ALL model. Blood. 113:6172-6181. doi:10.1182/blood-2008-02-136762

Del Bianco, C., A. Vedenko, S.H. Choi, M.F. Berger, L. Shokri, M.L. Bulyk, and S.C. Blacklow. 2010. Notch and MAML-1 complexation do not detectably alter the DNA binding specificity of the transcription factor CSL. PLoS ONE. 5:e15034. doi:10.1371/journal .pone.0015034

Dibirdik, I., M.C. Langlie, J.A. Ledbetter, L. Tuel-Ahlgren, V. Obuz, K.G. Waddick, K. Gajl-Peczalska, G.L. Schieven, and F.M. Uckun. 1991. Engagement of interleukin-7 receptor stimulates tyrosine phosphorylation, phosphoinositide turnover, and clonal proliferation of human T-lineage acute lymphoblastic leukemia cells. Blood. 78:564-570.

Fernandez, P.C., S.R. Frank, L. Wang, M. Schroeder, S. Liu, J. Greene, A. Cocito, and B. Amati. 2003. Genomic targets of the human c-Myc protein. Genes Dev. 17:1115-1129. doi:10.1101/gad.1067003

Gerby, B., E. Clappier, F. Armstrong, C. Deswarte, J. Calvo, S. Poglio, J. Soulier, N. Boissel, T. Leblanc, A. Baruchel, et al. 2011. Expression of CD34 and CD7 on human T-cell acute lymphoblastic leukemia discriminates functionally heterogeneous cell populations. Leukemia. (Epub ahead of print).

González-García, S., M. García-Peydró, E. Martín-Gayo, E. Ballestar, M. Esteller, R. Bornstein, J.L. de la Pompa, A.A. Ferrando, and M.L. Toribio. 2009. CSL-MAML-dependent Notch1 signaling controls T lineage-specific IL-7R $\alpha$ gene expression in early human thymopoiesis and leukemia. J. Exp. Med. 206:779-791. doi:10.1084/ jem.20081922

Greer, E.L., and A. Brunet. 2005. FOXO transcription factors at the interface between longevity and tumor suppression. Oncogene. 24:74107425. doi:10.1038/sj.onc.1209086

Guo, W., J.L. Lasky, C.J. Chang, S. Mosessian, X. Lewis, Y. Xiao, J.E. Yeh, J.Y. Chen, M.L. Iruela-Arispe, M. Varella-Garcia, and H. Wu. 2008. Multi-genetic events collaboratively contribute to Pten-null leukaemia stem-cell formation. Nature. 453:529-533. doi:10.1038/ nature 06933 
Gutierrez, A., T. Sanda, R. Grebliunaite, A. Carracedo, L. Salmena, Y. Ahn, S. Dahlberg, D. Neuberg, L.A. Moreau, S.S. Winter, et al. 2009. High frequency of PTEN, PI3K, and AKT abnormalities in T-cell acute lymphoblastic leukemia. Blood. 114:647-650. doi:10.1182/ blood-2009-02-206722

Hatzis, P., and I. Talianidis. 2002. Dynamics of enhancer-promoter communication during differentiation-induced gene activation. Mol. Cell. 10:1467-1477. doi:10.1016/S1097-2765(02)00786-4

Heintzman, N.D., R.K. Stuart, G. Hon, Y. Fu, C.W. Ching, R.D. Hawkins, L.O. Barrera, S. Van Calcar, C. Qu, K.A. Ching, et al. 2007. Distinct and predictive chromatin signatures of transcriptional promoters and enhancers in the human genome. Nat. Genet. 39:311-318. doi:10.1038/ ng1966

Holzenberger, M., P. Leneuve, G. Hamard, B. Ducos, L. Perin, M. Binoux, and Y. Le Bouc. 2000. A targeted partial invalidation of the insulin-like growth factor I receptor gene in mice causes a postnatal growth deficit. Endocrinology. 141:2557-2566. doi:10.1210/en.141.7.2557

Ivanova, N.B., J.T. Dimos, C. Schaniel, J.A. Hackney, K.A. Moore, and I.R. Lemischka. 2002. A stem cell molecular signature. Science. 298:601-604. doi:10.1126/science.1073823

Jarriault, S., C. Brou, F. Logeat, E.H. Schroeter, R. Kopan, and A. Israel. 1995. Signalling downstream of activated mammalian Notch. Nature. 377:355-358. doi:10.1038/377355a0

Ji, H., H. Jiang, W. Ma, D.S. Johnson, R.M. Myers, and W.H. Wong. 2008. An integrated software system for analyzing ChIP-chip and ChIPseq data. Nat. Biotechnol. 26:1293-1300. doi:10.1038/nbt.1505

Kawamura, M., H. Ohnishi, S.-X. Guo, X.M. Sheng, M. Minegishi, R. Hanada, K. Horibe, T. Hongo, Y. Kaneko, F. Bessho, et al. 1999. Alterations of the p53, p21, p16, p15 and RAS genes in childhood T-cell acute lymphoblastic leukemia. Leuk. Res. 23:115-126. doi:10.1016/S0145-2126(98)00146-5

Kirmizis, A., S.M. Bartley, A. Kuzmichev, R. Margueron, D. Reinberg, R. Green, and P.J. Farnham. 2004. Silencing of human polycomb target genes is associated with methylation of histone H3 Lys 27. Genes Dev. 18:1592-1605. doi:10.1101/gad.1200204

Krejcí, A., and S. Bray. 2007. Notch activation stimulates transient and selective binding of $\mathrm{Su}(\mathrm{H}) / \mathrm{CSL}$ to target enhancers. Genes Dev. 21:13221327. doi:10.1101/gad. 424607

Leneuve, P., R. Zaoui, P. Monget, Y. Le Bouc, and M. Holzenberger. 2001. Genotyping of Cre-lox mice and detection of tissue-specific recombination by multiplex PCR. Biotechniques. 31:1156-1160: 1162.

Levy, D.S., J.A. Kahana, and R. Kumar. 2009. AKT inhibitor, GSK690693, induces growth inhibition and apoptosis in acute lymphoblastic leukemia cell lines. Blood. 113:1723-1729. doi:10.1182/blood-2008-02-137737

Liu, H., A.W.S. Chi, K.L. Arnett, M.Y. Chiang, L. Xu, O. Shestova, H. Wang, Y.-M. Li, A. Bhandoola, J.C. Aster, et al. 2010. Notch dimerization is required for leukemogenesis and T-cell development. Genes Dev. 24:2395-2407. doi:10.1101/gad.1975210

Maillard, I., A.P. Weng, A.C. Carpenter, C.G. Rodriguez, H. Sai, L. Xu, D. Allman, J.C. Aster, and W.S. Pear. 2004. Mastermind critically regulates Notch-mediated lymphoid cell fate decisions. Blood. 104:1696-1702. doi:10.1182/blood-2004-02-0514

Maser, R.S., B. Choudhury, P.J. Campbell, B. Feng, K.K. Wong, A. Protopopov, J. O’Neil, A. Gutierrez, E. Ivanova, I. Perna, et al. 2007. Chromosomally unstable mouse tumours have genomic alterations similar to diverse human cancers. Nature. 447:966-971. doi:10.1038/nature05886

Medyouf, H., X. Gao, F. Armstrong, S. Gusscott, Q. Liu, A.L. Gedman, L.H. Matherly, K.R. Schultz, F. Pflumio, M.J. You, and A.P. Weng. 2010. Acute T-cell leukemias remain dependent on Notch signaling despite PTEN and INK4A/ARF loss. Blood. 115:1175-1184. doi:10.1182/ blood-2009-04-214718

O’Neil, J., J. Grim, P. Strack, S. Rao, D. Tibbitts, C. Winter, J. Hardwick, M. Welcker, J.P. Meijerink, R. Pieters, et al. 2007. FBW7 mutations in leukemic cells mediate NOTCH pathway activation and resistance to $\gamma$-secretase inhibitors. J. Exp. Med. 204:1813-1824. doi:10.1084/ jem. 20070876

Odom, D.T., R.D. Dowell, E.S. Jacobsen, W. Gordon, T.W. Danford, K.D. MacIsaac, P.A. Rolfe, C.M. Conboy, D.K. Gifford, and E. Fraenkel. 2007. Tissue-specific transcriptional regulation has diverged significantly between human and mouse. Nat. Genet. 39:730-732. doi:10.1038/ng2047

Palomero, T., K.C. Barnes, P.J. Real, J.L. Glade Bender, M.L. Sulis, V.V. Murty, A.I. Colovai, M. Balbin, and A.A. Ferrando. 2006a. CUTLL1, a novel human T-cell lymphoma cell line with $t(7 ; 9)$ rearrangement, aberrant NOTCH1 activation and high sensitivity to gamma-secretase inhibitors. Lenkemia. 20:1279-1287. doi:10.1038/sj.leu.2404258

Palomero, T., W.K. Lim, D.T. Odom, M.L. Sulis, P.J. Real, A Margolin, K.C. Barnes, J. O'Neil, D. Neuberg, A.P. Weng, et al. 2006b. NOTCH1 directly regulates c-MYC and activates a feedforward-loop transcriptional network promoting leukemic cell growth. Proc. Natl. Acad. Sci. USA. 103:18261-18266. doi:10.1073/ pnas. 0606108103

Palomero, T., M.L. Sulis, M. Cortina, P.J. Real, K. Barnes, M. Ciofani, E. Caparros, J. Buteau, K. Brown, S.L. Perkins, et al. 2007. Mutational loss of PTEN induces resistance to NOTCH1 inhibition in T-cell leukemia. Nat. Med. 13:1203-1210. doi:10.1038/nm1636

Pear, W.S., J.C. Aster, M.L. Scott, R.P. Hasserjian, B. Soffer, J. Sklar, and D. Baltimore. 1996. Exclusive development of T cell neoplasms in mice transplanted with bone marrow expressing activated Notch alleles. J. Exp. Med. 183:2283-2291. doi:10.1084/jem.183.5.2283

Perentesis, J.P., S. Bhatia, E. Boyle, Y. Shao, X.O. Shu, M. Steinbuch, H.N. Sather, P. Gaynon, W. Kiffmeyer, J. Envall-Fox, and L.L. Robison. 2004. RAS oncogene mutations and outcome of therapy for childhood acute lymphoblastic leukemia. Lenkemia. 18:685-692. doi:10.1038/sj.leu.2403272

Pollak, M.N., E.S. Schernhammer, and S.E. Hankinson. 2004. Insulin-like growth factors and neoplasia. Nat. Rev. Cancer. 4:505-518. doi:10.1038/ $\operatorname{nrc1387}$

Quintana, E., M. Shackleton, M.S. Sabel, D.R. Fullen, T.M. Johnson, and S.J. Morrison. 2008. Efficient tumour formation by single human melanoma cells. Nature. 456:593-598. doi:10.1038/nature07567

Sanda, T., X. Li, A. Gutierrez, Y. Ahn, D.S. Neuberg, J. O'Neil, P.R. Strack, C.G. Winter, S.S. Winter, R.S. Larson, et al. 2010 Interconnecting molecular pathways in the pathogenesis and drug sensitivity of T-cell acute lymphoblastic leukemia. Blood. 115:1735-1745. doi:10.1182/blood-2009-07-235143

Schadt, E.E., C. Li, B. Ellis, and W.H. Wong. 2001. Feature extraction and normalization algorithms for high-density oligonucleotide gene expression array data. J. Cell. Biochem. Suppl. 37(Suppl 37):120-125. doi:10 $.1002 /$ jcb.10073

Sharma, V.M., J.A. Calvo, K.M. Draheim, L.A. Cunningham, N. Hermance, L. Beverly, V. Krishnamoorthy, M. Bhasin, A.J. Capobianco, and M.A. Kelliher. 2006. Notch1 contributes to mouse T-cell leukemia by directly inducing the expression of c-myc. Mol. Cell. Biol. 26:8022-8031. doi:10.1128/MCB.01091-06

Shochat, C., N. Tal, O.R. Bandapalli, C. Palmi, I. Ganmore, G. te Kronnie, G. Cario, G. Cazzaniga, A.E. Kulozik, M. Stanulla, et al. 2011. Gain-of-function mutations in interleukin-7 receptor- $\alpha$ (IL7R) in childhood acute lymphoblastic leukemias. J. Exp. Med. 208:901-908. doi:10.1084/jem.20110580

Silva, A., J.A. Yunes, B.A. Cardoso, L.R. Martins, P.Y. Jotta, M. Abecasis, A.E. Nowill, N.R. Leslie, A.A. Cardoso, and J.T. Barata. 2008. PTEN posttranslational inactivation and hyperactivation of the PI3K/Akt pathway sustain primary $\mathrm{T}$ cell leukemia viability. J. Clin. Invest. 118:37623774. doi:10.1172/JCI34616

Silva, A., A.B.A. Laranjeira, L.R. Martins, B.A. Cardoso, J. Demengeot, J.A. Yunes, B. Seddon, and J.T. Barata. 2011. IL-7 contributes to human T-cell acute lymphoblastic leukemia progression in vivo. Cancer Res. 71:4780-4789.

Takahashi, K., and S. Yamanaka. 2006. Induction of pluripotent stem cells from mouse embryonic and adult fibroblast cultures by defined factors. Cell. 126:663-676. doi:10.1016/j.cell.2006.07.024

Takahashi, K., K. Tanabe, M. Ohnuki, M. Narita, T. Ichisaka, K. Tomoda, and S. Yamanaka. 2007. Induction of pluripotent stem cells from adult human fibroblasts by defined factors. Cell. 131:861-872. doi:10.1016/j.cell.2007.11.019

Thompson, B.J., S. Buonamici, M.L. Sulis, T. Palomero, T. Vilimas, G. Basso, A. Ferrando, and I. Aifantis. 2007. The SCFFBW7 ubiquitin 
ligase complex as a tumor suppressor in T cell leukemia. J. Exp. Med. 204:1825-1835. doi:10.1084/jem.20070872

Tremblay, M., C.S. Tremblay, S. Herblot, P.D. Aplan, J. Hébert, C. Perreault, and T. Hoang. 2010. Modeling T-cell acute lymphoblastic leukemia induced by the SCL and LMO1 oncogenes. Genes Dev. 24:1093-1105. doi:10.1101/gad.1897910

Wang, Q., J.S. Carroll, and M. Brown. 2005. Spatial and temporal recruitment of androgen receptor and its coactivators involves chromosomal looping and polymerase tracking. Mol. Cell. 19:631-642. doi:10.1016/ j.molcel.2005.07.018

Wang, H., J.Y. Zou, B. Zhao, E. Johannsen, T. Ashworth, H. Wong, W.S. Pear, J. Schug, S.C. Blacklow, K.L. Arnett, et al. 2011. Genome-wide analysis reveals conserved and divergent features of Notch1/RBPJ binding in human and murine T-lymphoblastic leukemia cells. Proc. Natl. Acad. Sci. USA. doi: 10.1073/pnas.1109023108.

Wei, G., D. Twomey, J. Lamb, K. Schlis, J. Agarwal, R. W. Stam, J.T. Opferman, S.E. Sallan, M.L. den Boer, R. Pieters, et al. 2006. Gene expression-based chemical genomics identifies rapamycin as a modulator of MCL1 and glucocorticoid resistance. Cancer Cell. 10:331-342. doi:10.1016/j.ccr.2006.09.006

Weng, A.P., Y. Nam, M.S. Wolfe, W.S. Pear, J.D. Griffin, S.C. Blacklow, and J.C. Aster. 2003. Growth suppression of pre-T acute lymphoblastic leukemia cells by inhibition of notch signaling. Mol. Cell. Biol. 23:655664. doi:10.1128/MCB.23.2.655-664.2003

Weng, A.P., A.A. Ferrando, W. Lee, J.P. Morris IV, L.B. Silverman, C. Sanchez-Irizarry, S.C. Blacklow, A.T. Look, and J.C. Aster. 2004. Activating mutations of NOTCH1 in human T cell acute lymphoblastic leukemia. Science. 306:269-271. doi:10.1126/science. 1102160

Weng, A.P., J.M. Millholland, Y. Yashiro-Ohtani, M.L. Arcangeli, A. Lau, C. Wai, C. Del Bianco, C.G. Rodriguez, H. Sai, J. Tobias, et al. 2006. c-Myc is an important direct target of Notch1 in T-cell acute lymphoblastic leukemia/lymphoma. Genes Dev. 20:2096-2109. doi:10 $.1101 /$ gad.1450406

Wittman, M., J. Carboni, R. Attar, B. Balasubramanian, P. Balimane, P. Brassil, F. Beaulieu, C. Chang, W. Clarke, J. Dell, et al. 2005. Discovery of a (1H-benzoimidazol-2-yl)-1H-pyridin-2-one (BMS536924) inhibitor of insulin-like growth factor I receptor kinase with in vivo antitumor activity. J. Med. Chem. 48:5639-5643. doi:10.1021/ jm050392q

Yilmaz, O.H., R. Valdez, B.K. Theisen, W. Guo, D.O. Ferguson, H. Wu, and S.J. Morrison. 2006. Pten dependence distinguishes haematopoietic stem cells from leukaemia-initiating cells. Nature. 441:475-482. doi:10.1038/nature04703 